Prepared for the U.S. Department of Energy

under Contract DE-AC05-76RL01830

\title{
Assessment of the National Wind Coordinating Collaborative: Addressing Environmental and Siting Issues Associated with Wind Energy Development
}

\section{FB Van Cleve JC States}

November 2010

Pacific Northwest

NATIONAL LABORATORY

Proudly Operated by Battelle Since 1965 



\title{
DISCLAIMER
}

This report was prepared as an account of work sponsored by an agency of the United States Government. Neither the United States Government nor any agency thereof, nor Battelle Memorial Institute, nor any of their employees, makes any warranty, express or implied, or assumes any legal liability or responsibility for the accuracy, completeness, or usefulness of any information, apparatus, product, or process disclosed, or represents that its use would not infringe privately owned rights. Reference herein to any specific commercial product, process, or service by trade name, trademark, manufacturer, or otherwise does not necessarily constitute or imply its endorsement, recommendation, or favoring by the United States Government or any agency thereof, or Battelle Memorial Institute. The views and opinions of authors expressed herein do not necessarily state or reflect those of the United States Government or any agency thereof.

\author{
PACIFIC NORTHWEST NATIONAL LABORATORY \\ operated by \\ BATTELLE \\ for the \\ UNITED STATES DEPARTMENT OF ENERGY \\ under Contract DE-AC05-76RL01830
}

Printed in the United States of America
Available to DOE and DOE contractors from the
Office of Scientific and Technical Information,
P.O. Box 62, Oak Ridge, TN 37831-0062;
ph: (865) 576-8401
fax: (865) 576-5728
email: reports@adonis.osti.gov

\begin{abstract}
Available to the public from the National Technical Information Service,
U.S. Department of Commerce, 5285 Port Royal Rd., Springfield, VA 22161

ph: (800) 553-6847

fax: $(703) 605-6900$

email: orders@ntis.fedworld.gov

online ordering: http://www.ntis.gov/ordering.htm
\end{abstract}

This document was printed on recycled paper. 



\section{Assessment of the National Wind Coordinating Collaborative: Addressing Environmental and Siting Issues Associated with Wind Energy Development}

FB Van Cleve

JC States

November 2010

Prepared for

the U.S. Department of Energy

under Contract DE-AC05-76RL01830

Pacific Northwest National Laboratory

Richland, Washington 99352 



\section{Summary}

The National Wind Coordinating Collaborative (NWCC) is a consensus-based stakeholder group comprised of representatives from the utility, wind industry, environmental, consumer, regulatory, power marketer, agricultural, tribal, economic development, and state and federal government sectors. The purpose of the NWCC is to support the development of an environmentally, economically, and politically sustainable commercial market for wind power (NWCC 2010). The NWCC has been funded by the U.S. Department of Energy (DOE) since its inception in 1994.

In order to evaluate the impact of the work of the NWCC and how this work aligns with DOE's strategic priorities, DOE tasked Pacific Northwest National Laboratory (PNNL) to conduct a series of informal interviews with a small sample of those involved with NWCC. The focus of this study was the Wildlife Workgroup (WW), a subgroup of the NWCC, but respondents and respondents' answers were not constrained to this workgroup alone. PNNL interviewed 22 key informants. Interviews consisted of 12 basic questions to assess the respondent's involvement in the NWCC, respondent's view of the value of NWCC, and NWCC funding options.

This study found broad support for the function of the NWCC/WW and highlights some suggestions to improve the quality of the services and products provided by the NWCC/WW. All but one respondent reported that environmental and siting issues are substantial barriers to wind energy development and several felt these issues are becoming more difficult. Over two-thirds of respondents said that the NWCC/WW had made a difference in resolving environmental and siting issues. Some provided specific examples of products or events while others said the contribution had been made in more general areas of collaboration, building understanding and relationships, and identification of issues. The remaining one third of respondents who did not believe that the NWCC had made a difference or who were undecided primarily came from natural resource agencies and industry. These respondents generally articulated disappointment that NWCC had not addressed 'big issues' or they cited the slowness of both the collaborative and scientific process and challenges inherent in developing regulations for a new industry as reasons why it was hard to determine whether the NWCC/WW had made a difference.

The opportunity to collaborate with a variety of key stakeholders was the reason most mentioned by respondents for their involvement in the NWCC/WW. The services or products most often cited as valuable were the semi-annual research conference and research synthesis documents. These synthesis documents, however, also generated criticism from some respondents who were dissatisfied with their quality or utility. Although some respondents were disappointed with the NWCC's ability to address big issues or felt that the NWCC overlaps with other organizations, nearly all respondents expressed that discontinuation of the NWCC at this point would have negative consequences, including more polarization on environmental and siting issues, regression of issues previously considered solvable to intractable, lost attention to wildlife issues, and less idea and information sharing. Several respondents see the NWCC as an important mechanism to achieve DOE's stated goal of " $20 \%$ renewable energy by 2030" because the NWCC promotes agreement on technical issues and critical buy-in on consensus-based solutions.

Recommendations and points for further discussion among NWCC members and the DOE include: 
- Distinctions in roles and points of collaboration between the AWWI and NWCC should be clarified. For example, the NWCC/WW should evaluate whether its role should be to conduct research, synthesize research, or both. Completion and release of the NWCC-AWWI MOU may help, but more details may be necessary.

- NWCC products could be made more useful to the target audience by improved outreach of products to state natural resource agencies, a higher level of detail and sophistication, and separation of scientific findings from a consensus-based editing process.

- NWCC's purpose and role should be discussed and clarified among its members and also with DOE. Specifically, NWCC should have a clear sense of whether the forum is expected to raise and solve big issues or areas of conflict relating to wind energy development and wildlife issues. This topic should be addressed considering the implications for participation on NWCC (i.e. who needs to be at the table). Tension about whether the NWCC serves as a neutral forum or promotes responsible wind development should also be discussed among NWCC members. 


\section{Acknowledgments}

We would like to acknowledge the participation of the wide range of NWCC participants who agreed to share their thoughts and ideas about the NWCC during this study. We are also grateful to the staff of the NWCC for encouraging members of the NWCC to participate in this project. Interview notes were taken by Jennifer Cameron at Pacific Northwest National Laboratory. This study was funded and directed by the U.S. Department of Energy Wind and Water Power Office. 


\section{Acronyms and Abbreviations}

AWWI - American Wind and Wildlife Collaborative

NWCC - National Wind Coordinating Collaborative

PNNL - Pacific Northwest National Laboratory

DOE - U.S. Department of Energy

WW - Wildlife Workgroup 


\section{Contents}

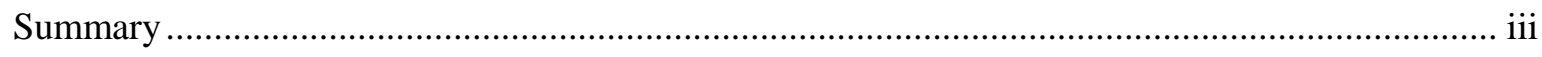

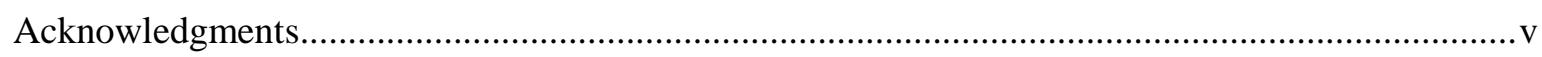

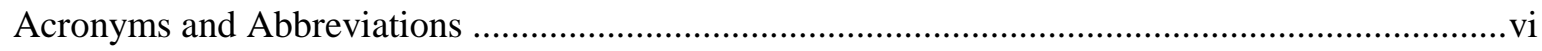

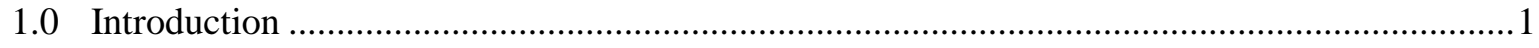

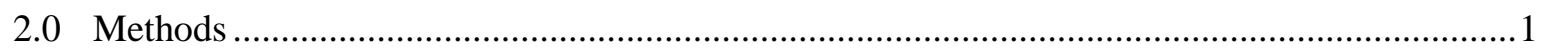

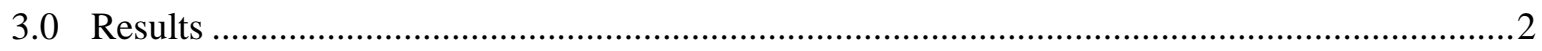

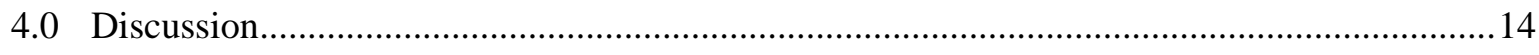

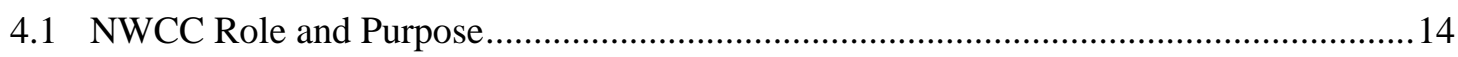

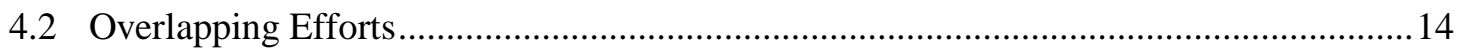

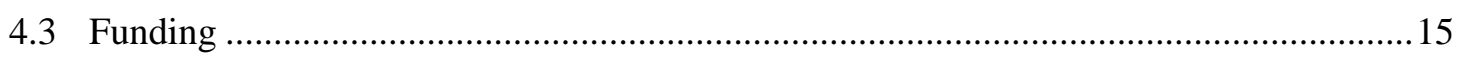

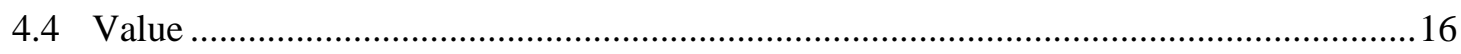

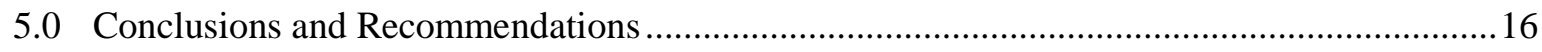

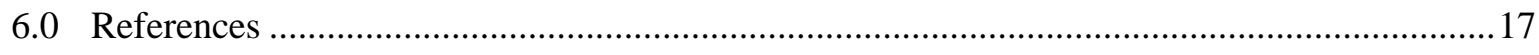

Appendix A: Reasons for Involvement in the NWCC ............................................................. 18

Appendix B: Activities, Services, Products of Most Value ............................................................21

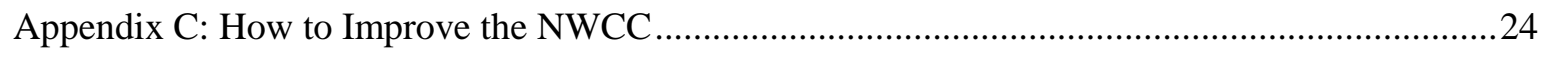

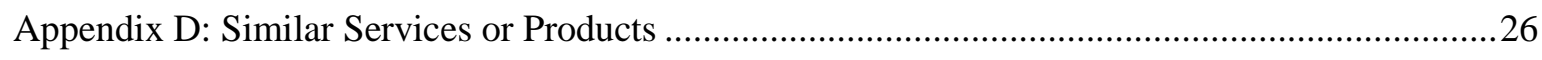

Appendix E: Consequences of Discontinuation of the NWCC …............................................28

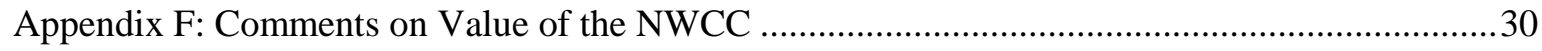




\section{Figures}

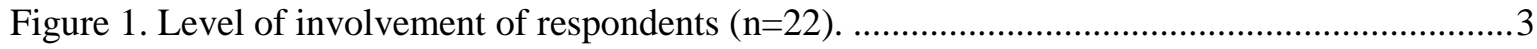

Figure 2. Reasons cited to explain why respondents are involved with the NWCC/WW.................4

Figure 3. Activities or products of the NWCC/WW cited as "most valuable" by respondents.........5

Figure 4. Whether environmental and siting issues remain a major barrier to wind development

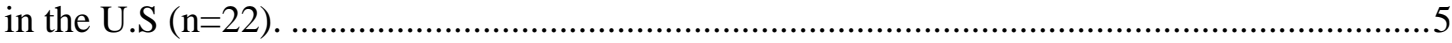

Figure 5. The best ways to resolve environmental or siting issues, in general terms. ......................6

Figure 6. Whether the NWCC/WW has made a difference in solving environmental or siting

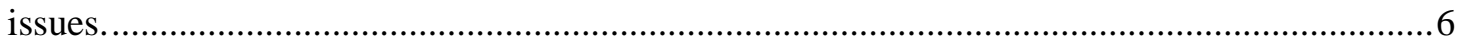

Figure 7. Whether other entities provide services redundant to those of the NWCC/WW..............9

Figure 8. Whether federal funding is critical to the successful operation of the NWCC.................11

Figure 9. Potential for alternative sources of funds to support NWCC ........................................ 12

\section{Tables}

Table 1. Basic interview questions. Clarifying questions are also shown. ...................................... 1

Table 2. Responses by sector to whether the NWCC/WW has made a difference...........................7

Table 3. Summarized responses for how the NWCC/WW could improve its work..........................8

Table 4. Consequences to environmental and siting issues if the NWCC were discontinued..........10

Table 5. Final comments on the value of the NWCC.................................................................. 13 


\subsection{Introduction}

The National Wind Coordinating Collaborative (NWCC) is a consensus-based stakeholder group comprised of representatives from the utility, wind industry, environmental, consumer, regulatory, power marketer, agricultural, tribal, economic development, and state and federal government sectors. The purpose of the NWCC is to support the development of an environmentally, economically, and politically sustainable commercial market for wind power (NWCC 2010).

Since its inception in 1994, the U.S. Department of Energy (DOE) has provided funding to support NWCC through a contract with Resolve, Inc., a non-profit mediation and facilitation organization. The current five-year contract ends on December 1, 2011. Because the NWCC is entering the last year of its current contract, DOE is evaluating the impact of the work of the NWCC and how this work aligns with DOE's strategic priorities. In order to support this evaluation, DOE tasked Pacific Northwest National Laboratory (PNNL) to conduct a series of informal interviews with a small sample of those who have been involved with NWCC. The focus of this study was the Wildlife Workgroup (WW), a subgroup of the NWCC, but respondents and respondents' answers were not constrained to this workgroup alone. Results of this study will be used to inform DOE's decision about how to support the NWCC in the future.

\subsection{Methods}

Informal, semi-structured interviews (Kvale 1996) were conducted by PNNL over a period of three weeks in September and October, 2010. DOE identified 24 key informants and 22 of those identified were interviewed by PNNL. All interviews took place over the phone with the exception of one in-person interview. Interviews lasted approximately 30 minutes and consisted of 12 basic questions to assess the respondent's involvement in the NWCC, respondent's view of the value of NWCC, and NWCC funding options (Table 1). Consistent with the semi-structured approach, how questions were asked varied slightly and questions were added for clarification or omitted as appropriate. Interviews were confidential and study results are anonymous.

Following the interviews, typed transcripts were summarized and analyzed for common themes and major points. Detailed answers to questions are provided in appendices and the authors strongly recommend that readers review these answers for the most accurate and true representation of respondents' opinions and suggestions. However, in an attempt to highlight major themes, we binned the answers to 9 questions into thematic topics for graphical representation. Bins were developed by the authors after interviews were completed based on the breadth and details of responses.

Table 1. Basic interview questions. Clarifying questions are also shown.

Could you start by telling us a little about your involvement with NWCC's wildlife and siting work?

- What activities are you involved with? How long have you been involved? Are you a regular participant?

Do environmental and siting issues remain among the major barriers to developing wind energy in the U.S?

- Do you agree that this is one of the primary barriers? How important is it compared to other potential barriers (e.g. technological, transmission infrastructure, etc.)? 
In your experience, how are environmental and siting issues best resolved in general terms?

- In your view, how best can challenges associated with wind energy environmental and siting issues be overcome?

Why are you involved with the NWCC/WW?

- Could you tell us why you chose to be involved in the NWCC/WW? What is the benefit to you or your organization?

What activities/products of the NWCC/WW are most valuable?

- Based on your experience, can you give some examples of the services or products provided by NWCC/WW activities that you've found particularly valuable?

Has NWCC/WW made a difference in solving environmental and siting issues?

- Do you recall specific instances where the NWCC/WW made a difference?

How could NWCC/WW improve its work?

- Do you have specific ideas about how NWCC/WW could improve services or products provided?

Are others also providing services/products similar to the NWCC/WW?

- Is NWCC/WW unique in addressing these needs or are other groups or entities also addressing these needs? If others are addressing needs, who?

What if the NWCC were discontinued?

- If the NWCC were discontinued, in your opinion what would be the impact on the overall deployment of wind energy in the U.S? Would it increase, or decrease, and would the change be significant?

Is it important that NWCC funding come from the federal government, or DOE specifically? Or could funding come from a non-federal source?

- If the NWCC were funded by other groups or a "non-government" coalition of organizations, in your opinion would it have greater, or less, credibility, and would you and your sponsoring organization still participate? Why or why not?

Are there other funding approaches that could be explored?

- Are there cost-sharing arrangements that could be explored to ensure that the most valuable NWCC activities continue to be supported in the future? If so, with whom?

\section{Wrap up and final thoughts}

- Is there anything we didn't ask about that you think we should have? Did we forget anything? Are there any topics you'd like to return to?

\subsection{Results}

Respondents were grouped into five categories, including:

- Coalition (3 respondents) - broad stakeholder groups such as NWCC or AWWI

- Industry (6 respondents) - wind project developers and industry associations such as the American Wind Energy Association

- $\quad \mathrm{NGO}$ (3 respondents) - environmental non-governmental organizations

- Natural Resource Agency (5 respondents) - state and federal natural resource agencies

- Research or Consulting (5 respondents) - private or public research organizations 
This categorization was used to report the breadth of respondents and to evaluate varying opinions based on sectors in some cases. Over half of the respondents were very involved with the NWCC/WW (i.e., they served on the NWCC Steering Committee or had helped to launch the NWCC). Three of the 12 respondents we considered to be very involved were no longer involved with the NWCC. Six respondents reported attending NWCC, WW, or NWCC semi-annual research meetings regularly and 4 respondents reported limited involvement (i.e., attended meetings infrequently or one-time involvement in an event or topic) (Figure 1).

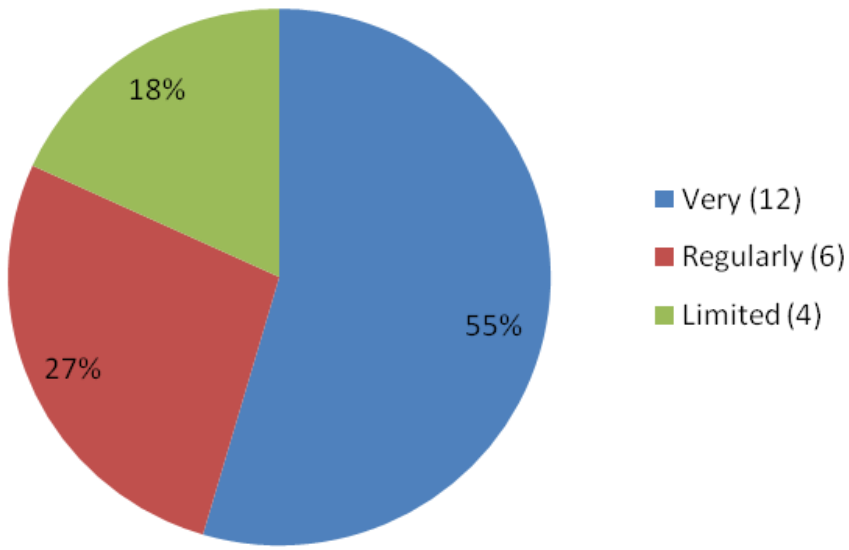

Figure 1. Level of involvement of respondents $(n=22)$.

When asked why they were involved with the NWCC/WW, respondents cited several reasons why the NWCC provides them or their organization with value. Over half of respondents cited the opportunity to collaborate with a broad range of people with relevance to environmental or siting issues. Eight people cited the opportunity to exchange information (both learn and share information with others) and 6 people cited the ability to discuss issues and concerns with other stakeholders. The ability of the NWCC to develop solutions to problems, provide a professional networking opportunity, and supply credible, technical information were each cited by 4 people as a reason for their involvement. The value of the NWCC/WW as a neutral forum was also cited by a respondent and other explanations included staffing responsibilities, to advise the NWCC/WW on technical issues, and to ensure sector representation (Figure 2). Many respondents cited more than one reason. Full answers are available in Appendix A. 


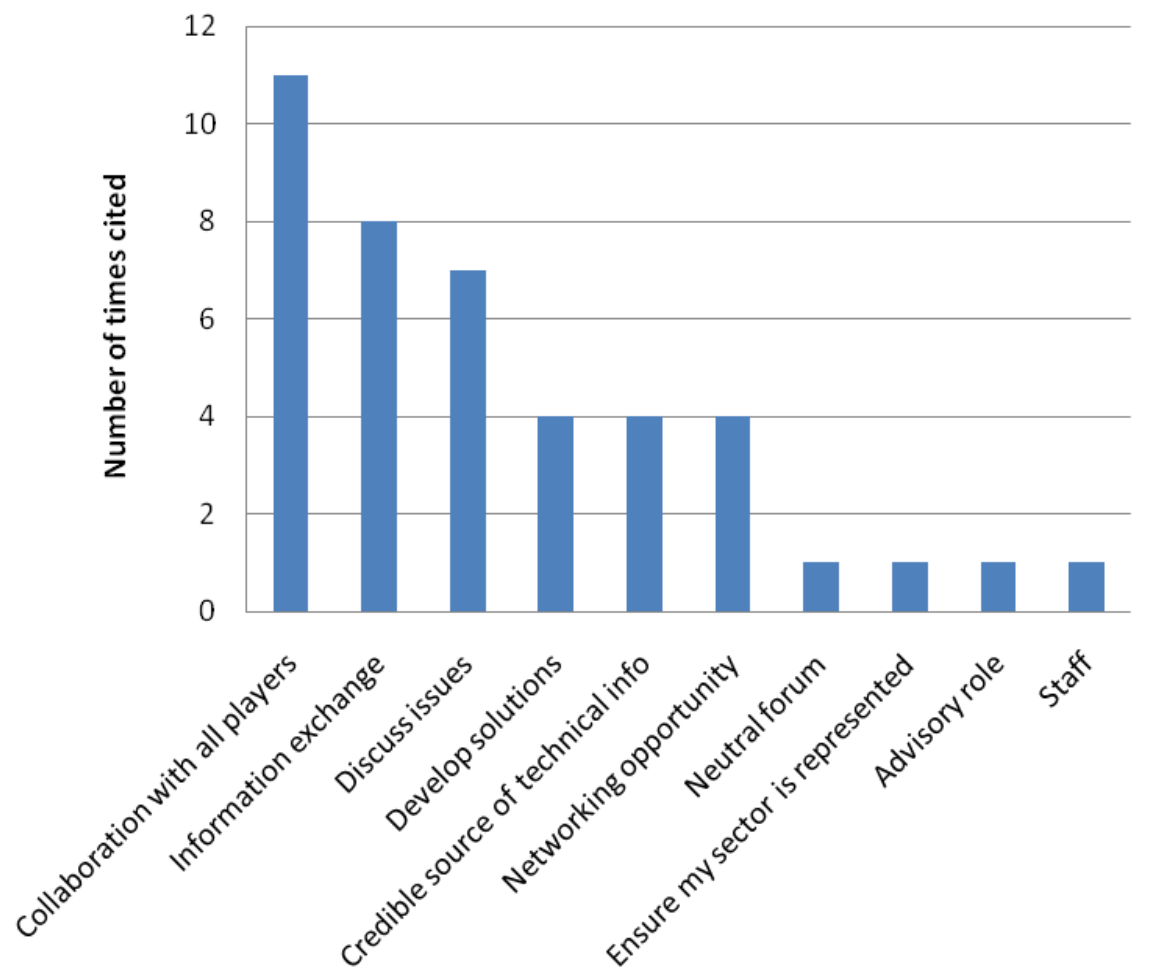

Figure 2. Reasons cited to explain why respondents are involved with the NWCC/WW.

When asked what products, activities, or services were most valuable to them, over half of respondents (13 each) cited synthesis of research on siting and wildlife interactions with wind turbines or the semi-annual NWCC research conference and conference proceedings as most valuable. Nine respondents named coordination as a high value service of the NWCC/WW. Three respondents cited each member education and the development of research priorities as highly valuable. One respondent had not been involved long enough to make a determination (Figure 3). Many respondents provided more than one answer. Full answers are available in Appendix B. 


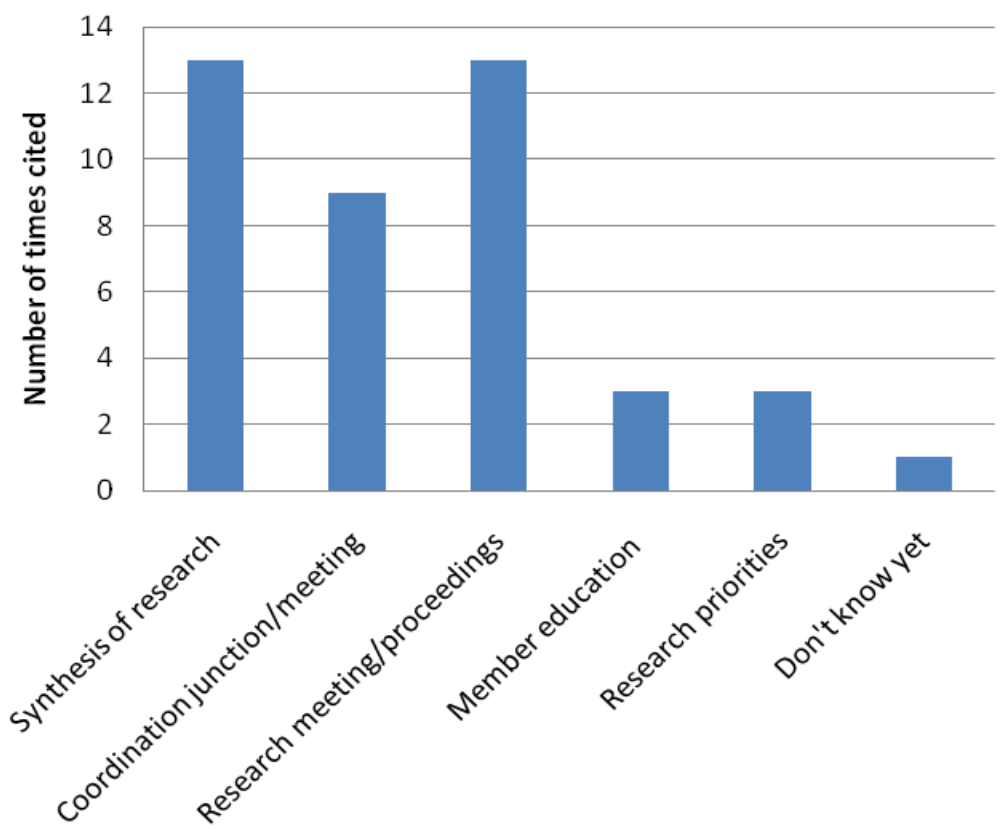

Figure 3. Activities or products of the NWCC/WW cited as "most valuable" by respondents.

The NWCC was formed at a time when wildlife issues threatened to halt wind development in the U.S. In order to understand how wildlife issues currently compare with other barriers to wind development (e.g., financing, transmission infrastructure, market demand), respondents were asked if, in their experience, environmental and siting issues remained one of the major barriers to wind development. Nearly three-quarters (15 people) of respondents felt that environmental and siting issues are still major barriers, while over one-quarter (6 people) felt that these issues are becoming even bigger barriers. One respondent felt that, while environmental and siting issues remain a major challenge to wind development, these issues are no longer a barrier to development because permitting pathways now exist at federal and state agencies. The respondent felt that the existence of this pathway was attributable to the work of the NWCC/WW (Figure 4).

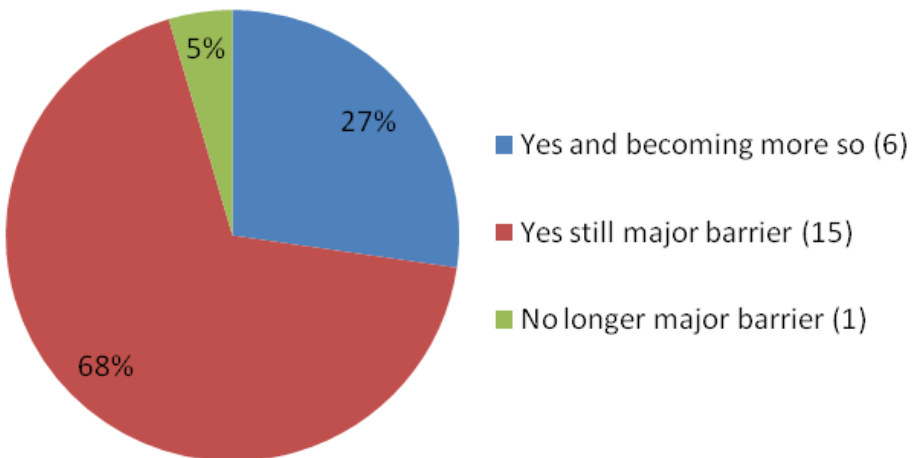

Figure 4. Whether environmental and siting issues remain a major barrier to wind development in the U.S $(n=22)$.

When asked how environmental and siting issues associated with wind development should best be addressed or resolved, respondents most often named research targeted to address specific technical questions and broad collaboration. Seven people cited credible synthesis of research and three people said that building understanding was important for resolving conflicts. Respondents also noted that 
appropriate siting of wind turbines was useful and that legal mechanisms can also be effective ways to resolve issues (Figure 5). Some respondents provided more than one answer.

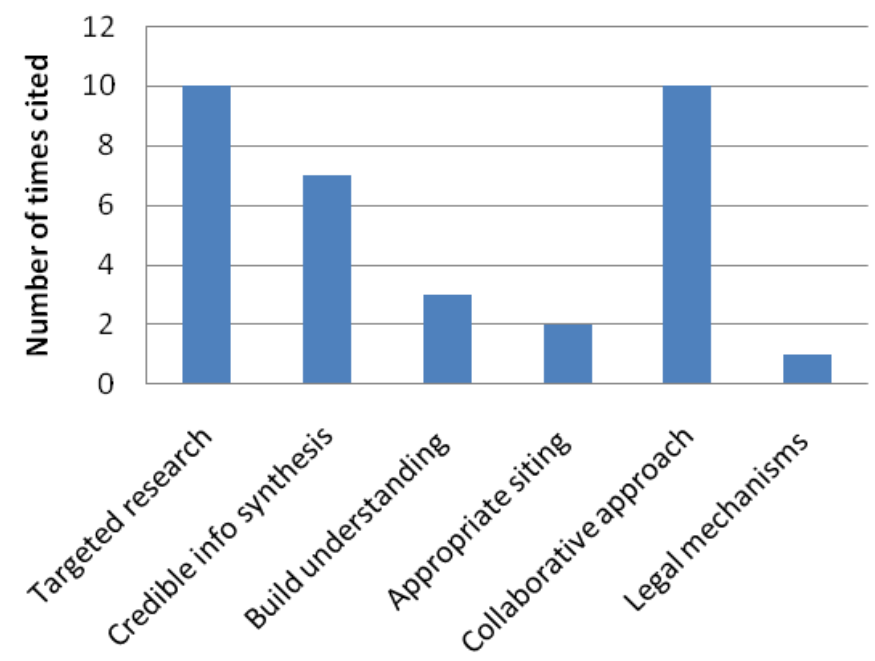

Figure 5. The best ways to resolve environmental or siting issues, in general terms.

When asked about the NWCC/WW's effectiveness in addressing environmental or siting issues, over two thirds (15) of respondents felt that the NWCC/WW had made a difference in resolving these issues. Four respondents said that they were as of yet undecided as to whether or not the NWCC/WW had made a difference and three respondents felt that the NWCC/WW had not made a difference in resolving environmental or siting issues (Figure 6). When examined by sector, all coalition and NGO respondents and 4 of 5 research/consultant respondents felt that NWCC/WW had made a difference. However, among industry and natural resource agency respondents, there was much more disagreement on this topic (Table 2).

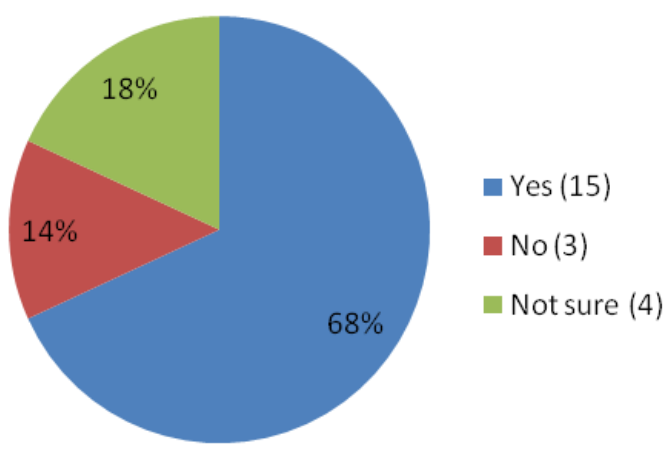

Figure 6. Whether the NWCC/WW has made a difference in solving environmental or siting issues. 
Table 2. Responses by sector to whether the NWCC/WW has made a difference.

\begin{tabular}{rrrr|r} 
& & & Not & \\
Coalition & No & sure & Total \\
\cline { 2 - 5 } Industry & 3 & 0 & 0 & 3 \\
\cline { 2 - 5 } Natural Resource Agency & 3 & 1 & 2 & 6 \\
\cline { 2 - 5 } NGO & 3 & 0 & 0 & 3 \\
\cline { 2 - 5 } Research/Consult & 4 & 1 & 0 & 5 \\
\cline { 2 - 5 } Total & 15 & 3 & 4 & \\
& $68 \%$ & $14 \%$ & $18 \%$ &
\end{tabular}

Respondents had a wide variety of ideas about how the NWCC/WW could improve its work. Table 3 provides a summary of answers. Full answers are presented in Appendix C. Some themes include:

- Improve utility of products with more targeted outreach of products to key audiences, such as state agencies

- Securing involvement from state agencies

- Retain relevance by moving on to or expanding NWCC's work to other renewable issues

- Reinvigorate NWCC and Steering Committee membership

- More frequent updates on and synthesis of scientific research findings through annual research conferences and electronic updates of relevant studies

- Improve the quality of products with broader authorship and more care separating scientific findings from alteration through the consensus process

- Consider expanding into offshore wind

- Relax the focus on getting to consensus to allow for dissenting opinions to be aired and addressed

- Take on the big issues and try to bring about real change

- Resolve funding shortfalls and uncertainties 
Table 3. Summarized responses for how the NWCC/WW could improve its work.

\begin{tabular}{|c|c|}
\hline \multirow{3}{*}{ : } & $\begin{array}{l}\text { Outreach of products, expand partnerships, serve as info clearing house, provide consensus-building } \\
\text { training, fund state involvement. }\end{array}$ \\
\hline & Rely less on volunteers \\
\hline & $\begin{array}{l}\text { More experienced staff (such as Abby), wildlife issues now have a process; move on to other } \\
\text { dysfunctional issues to catalyze action, new blood on Steering Committee (SC), engage agencies } \\
\text { more on SC, use webinars and email to broaden involvement in SC. }\end{array}$ \\
\hline \multirow{6}{*}{ 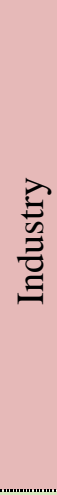 } & $\begin{array}{l}\text { More representation of industry. Make research meeting annual. More solution focused research. } \\
\text { Address personalities on NWCC who impede progress. }\end{array}$ \\
\hline & $\begin{array}{l}\text { Stay focused on big issues, "concurrence unless stated otherwise" on products isn't appropriate } \\
\text { considering level of importance; solution is hounding from sector reps on Steering Committee }\end{array}$ \\
\hline & Don't know \\
\hline & $\begin{array}{l}\text { Improve messaging about value of products to potential users. Ensure that products provide } \\
\text { intended value. }\end{array}$ \\
\hline & No ideas \\
\hline & $\begin{array}{l}\text { Stable funding and support from DOE (includes articulation of DOE priorities). Broaden focus to } \\
\text { issues common to all renewables. }\end{array}$ \\
\hline \multirow{5}{*}{ 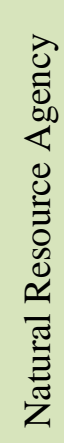 } & $\begin{array}{l}\text { Make products more useful to states (includes building capacity, messaging). Fund state } \\
\text { participation. Better coordination between NWCC workgroups. }\end{array}$ \\
\hline & Better coverage and reporting on fast breaking research results or issues. \\
\hline & $\begin{array}{l}\text { Produce more sophisticated and in-depth products; avoid watering down science in a consensus } \\
\text { process. Don't compromise the right outcome just to get to consensus. Solicit broader participation } \\
\text { in writing documents. }\end{array}$ \\
\hline & Don't know \\
\hline & More peer review and synthesis of referenced science literature. \\
\hline \multirow{3}{*}{ ○ } & $\begin{array}{l}\text { More frequent product updates (following product-specific timelines). Carefully consider role in } \\
\text { offshore wind. }\end{array}$ \\
\hline & $\begin{array}{l}\text { Provide leadership in categorizing offshore wind sites. Better coordination between NWCC } \\
\text { workgroups. }\end{array}$ \\
\hline & Establish best practices for the industry. NWCC should retool to be more effective. \\
\hline \multirow{5}{*}{ 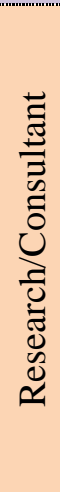 } & $\begin{array}{l}\text { Do a better job separating science from the consensus process. NWCC is balanced in terms of } \\
\text { members, but not outcomes. Biased towards industry/DOE interests. Opposition to wind energy } \\
\text { isn't taken seriously; should be met head on. }\end{array}$ \\
\hline & $\begin{array}{l}\text { Continue the function, but DOE should run a competitive solicitation to run it to rejuvenate interest } \\
\text { and show commitment (no bad reflection on Resolve). DOE would need to well define purpose and } \\
\text { functions. NWCC should expand to focus on environmental issues common to other renewables. }\end{array}$ \\
\hline & $\begin{array}{l}\text { Do a better job to bring about real change and broker projects to address big issues. NWCC should } \\
\text { focus on offshore wind. }\end{array}$ \\
\hline & Speed up product development/review timeline. Funding would help here. \\
\hline & Better funding would facilitate more work (and less energy spent fund raising) \\
\hline
\end{tabular}


When asked if other entities provided a similar function as the NWCC/WW, nearly half of respondents (10 people) said that NWCC/WW is unique in its function. Eight additional people said that no other entity has a redundant function, but noted that there is overlap of some functions with entities such as the American Wind and Wildlife Collaborative (AWWI), Great Lakes Wind Collaborative, and the U.S. Offshore Wind Collaborative. Only 2 respondents felt that there was significant overlap with the AWWI. Full answers are available in Appendix D.

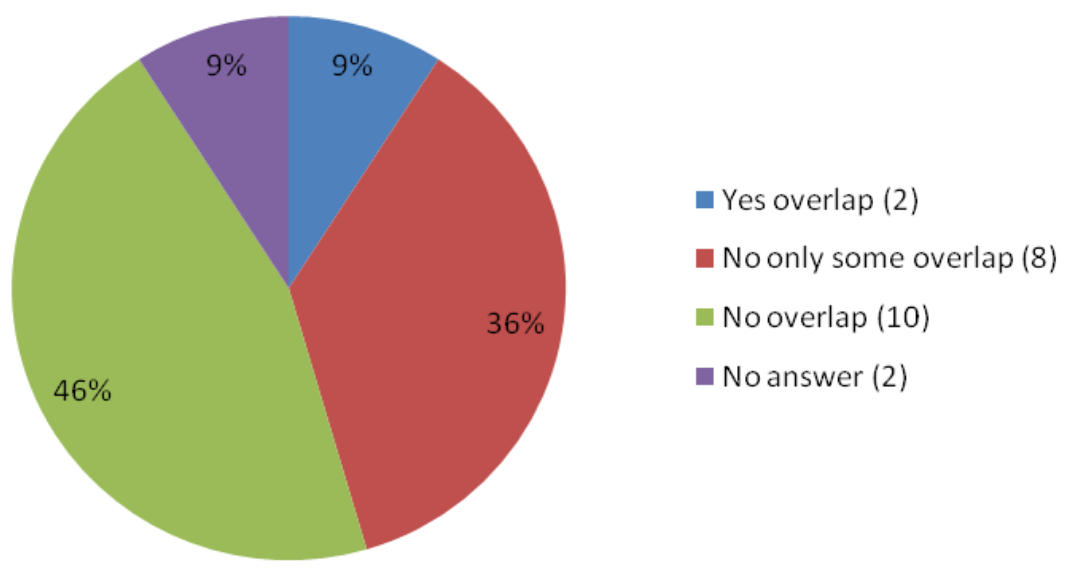

Figure 7. Whether other entities provide services redundant to those of the NWCC/WW.

As another way to determine the value of the NWCC, respondents were asked to describe what the impact would be on environmental and siting issues and wind development in the U.S. in general if the NWCC were discontinued. Ninety percent of respondents (20 out of 22) cited entirely negative consequences of discontinuation ranging from losing attention and technical detail on wildlife issues to loss of progress towards DOE's " $20 \%$ by 2030 " goals. Two industry respondents acknowledged the loss to non-industry stakeholders, but didn't think discontinuation of the NWCC would make a difference to industry (Table 4). Full answers are presented in Appendix E. 
Table 4. Consequences to environmental and siting issues if the NWCC were discontinued. Attention would be lost to wildlife issues. People would not be up to date. Lost support for .

Unfortunate. AWWI could take on some functions in the future (but not yet).

DOE would lose the pulse of what's happening. Back to poor info exchange. Lose ability to dig deeply into significant issues.

Don't think industry would miss it, although other stakeholders would. Not a bad idea to clean house (nothing against Resolve) to re-excite members. Someone would pick up the research meeting and DOE could put research \$ in to AWWI.

Lose helpful place to vet issues that no one else provides.

It'd be a bad thing. The level of info about wildlife impacts would decrease. AWWI would have to

章 take up some slack.

$\Xi$ Not much impact from industry perspective, but would be a loss of forum to have an open dialogue and exchange info.

Some issues would become thornier. Someone would need to pick up research meeting, but hard to find neutral party.

The network that can help us get to "20\% by 2030 " would function at a lower level.

We'd lose forum for collaboration and no one would pick it up. AWWI could move research

ठ্ forward, but they don't identify priorities.

$\underset{8}{\infty}$ Communication channel would be lost. Difficult to reestablish. And NWCC expertise.

o Not sure NWCC helped with siting issues, but member education would be lost.

$\simeq$ It's worth continuing because still big issues to solve.

莺

We'd lose the forum to discuss issues, learn, share thoughts. No one else would pick up.

We'd lose a very useful forum with very broad membership. Industry wouldn't suffer, but other members would.

$Z$ Less hard data and info sharing. Problems turning out to be solvable would regress to intractable.

Bad thing. Some loss, but not as much as if NWCC re-tooled.

No table to gather around.

ل्.

More polarization between industry and environmentalists. Communication and relationships would break down. No one out there to pick this up.

Wildlife issues would get bigger and nastier before they got addressed. Permitting would be more difficult, take longer, be more expensive.

Things would become very disjointed and inefficient. No mechanism to exchange information.

It would be horrible. No one else gets into the nitty gritty to answer the tough questions.

Respondents were asked to comment on how the work of the NWCC was funded and whether it was necessary that the federal government - or DOE specifically - provide funding. Ninety percent of respondents ( 20 out of 22 people) affirmed that federal funding was important. Eight respondents said that federal funding is important to ensure credibility, transparency, independence, or neutrality of the NWCC and its products while 7 people said that federal funding is important to ensure participation from a wide range of stakeholders. Nearly half of respondents (9 people) said that funding from DOE specifically was important because of DOE's mission to promote the responsible deployment of wind energy. Three people felt that federal funding was not especially important to the successful operation of the NWCC (Figure 8). 
Respondents listed several other mechanisms by which to fund the NWCC or specific activities/products, including membership fees, foundations (e.g. Energy Foundation and Hewlett Foundation), other federal agencies (e.g. USFWS), competitive grants, charging fees for products, and increasing the registration fee for the semi-annual research conference. However, only 2 respondents felt that these alternative funding sources were promising could be pursued while 17 respondents felt that these alternatives were not promising. Generally, those that felt these alternative sources were not promising were concerned that participation or use of products would decrease if stakeholders paid dues, paid higher fees for conferences, or if the public paid fees to use products. In addition, respondents felt that private foundations were unlikely to fund stakeholder collaboration work because foundations generally fund advocacy work rather than long-term, consensus-building efforts. Respondents felt that grants were useful for funding specific research activities only and that other agencies were unlikely to fund the NWCC (Figure 9).

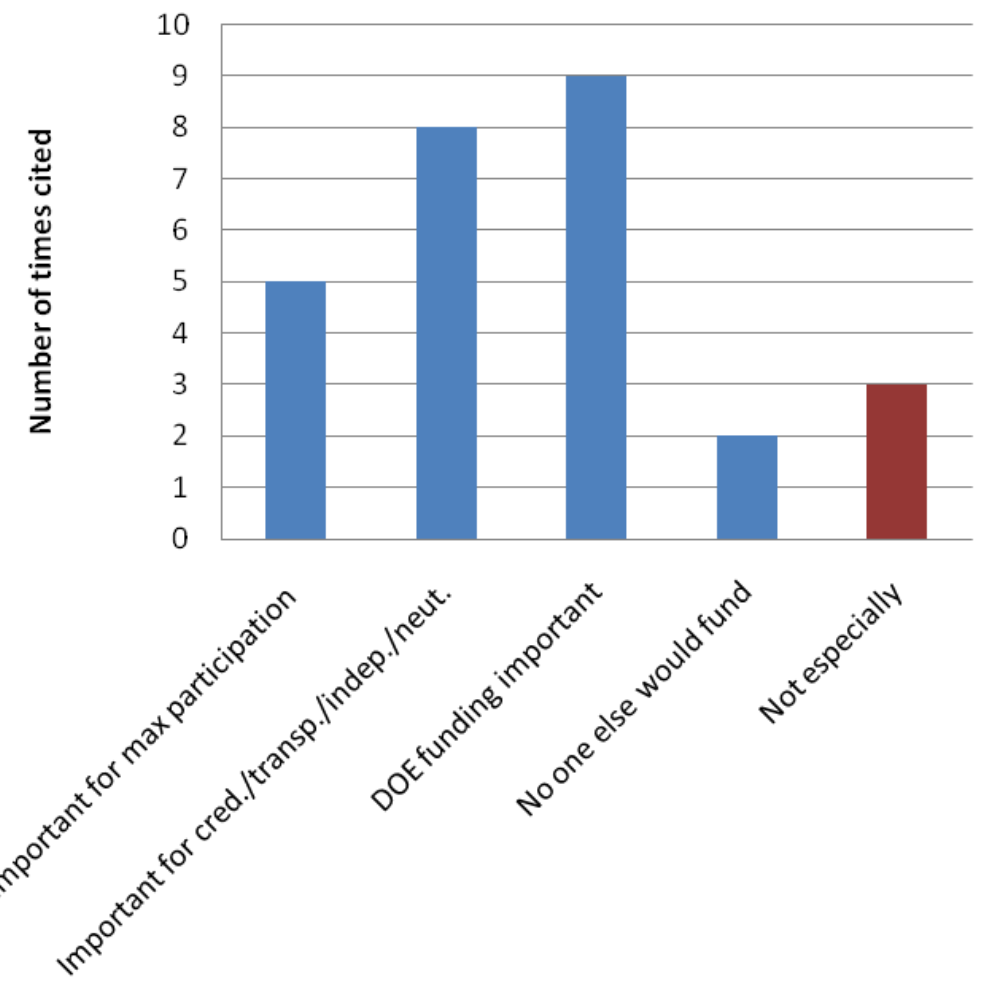

Figure 8. Whether federal funding is critical to the successful operation of the NWCC. 


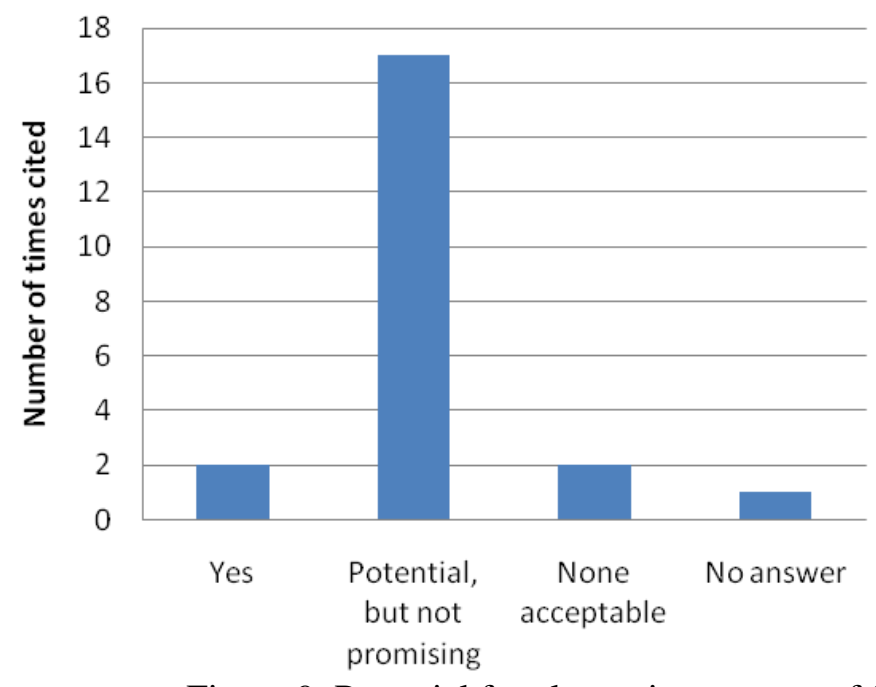

Figure 9. Potential for alternative sources of funds to support NWCC.

Finally, respondents were given the opportunity revisit past questions or make final observations about the questionnaire or the NWCC. Many respondents took this opportunity to make closing comments on the value of the NWCC. Summarized responses are presented in Table 5. Full answers are presented in Appendix F. 
Table 5. Final comments on the value of the NWCC.

\begin{tabular}{|c|c|}
\hline \multirow{2}{*}{ 葛 } & $\begin{array}{l}\text { Wildlife issues need resolution if wind contributes to a renewable energy future. Expertise at } \\
\text { NWCC extraordinarily valuable. }\end{array}$ \\
\hline & $\begin{array}{l}\text { Change agent. DOE wrong to only value technology development and not addressing uncertainty } \\
\text { collaboratively. }\end{array}$ \\
\hline \multirow{5}{*}{$\underset{\Xi}{\overparen{E}}$} & $\begin{array}{l}\text { Progress is exceedingly slow because everyone has a voice. Abby is best facilitator ever. Products } \\
\text { of limited utility. AWWI has better representation. }\end{array}$ \\
\hline & $\begin{array}{l}\text { Credibility. In depth dialogue. May be a role offshore. } \\
\text { Valuable to only address issues technically (not policy). Not sure if there is a practical use of } \\
\text { NWCC, but we'd be further behind without it. }\end{array}$ \\
\hline & $\begin{array}{l}\text { Products of limited value. Value is advancing scientific knowledge. Not effective at resolving } \\
\text { conflict. Losing federal funding would make it even less effective. }\end{array}$ \\
\hline & ---- \\
\hline & $\begin{array}{l}\text { NWCC convened dialogues on important topics and then spun them off for others to pick up. } \\
\text { NWCC forces agreements to be written down when they become real. DOE has no valid alternative } \\
\text { to what NWCC does. }\end{array}$ \\
\hline \multirow{5}{*}{ 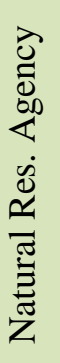 } & Relationship building \\
\hline & $\begin{array}{l}\text { Widely cited for expertise and products. Other organizations wouldn't be where they are if not for } \\
\text { NWCC. }\end{array}$ \\
\hline & --- \\
\hline & ---- \\
\hline & $\begin{array}{l}\text { Information dissemination to the public. Abby is good, strong facilitator. Representation is industry } \\
\text { heavy. }\end{array}$ \\
\hline \multirow{3}{*}{\begin{tabular}{l}
0 \\
\hdashline
\end{tabular}} & $\begin{array}{l}\text { Strength is its broad representation. Membership fee funding would make AWWI and NWCC too } \\
\text { similar. NWCC should consider its role in offshore wind. }\end{array}$ \\
\hline & 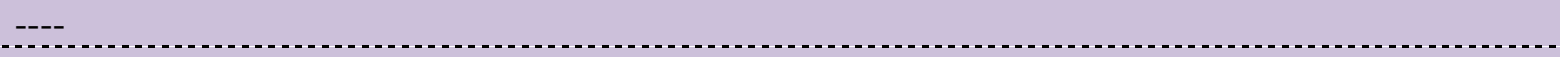 \\
\hline & Forum for dialogue. AWWI may diminish the importance of NWCC. DOE funding isn't unbiased. \\
\hline \multirow{5}{*}{ 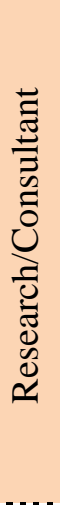 } & $\begin{array}{l}\text { NWCC has yet to solve complex problems. DOE and industry funding may be indistinguishable to } \\
\text { the public. Abby also very involved in many activities and perceptions matter. }\end{array}$ \\
\hline & $\begin{array}{l}\text { Unique forum without an agenda for info exchange. Catalyst for progress. Conferences are state of } \\
\text { the art. Products are credible and useful. }\end{array}$ \\
\hline & Collaboration. Exchange of information. Influential products. \\
\hline & $\begin{array}{l}\text { Significant value in the concept of NWCC. Forum for respectful dialogues. Facilitation is key to } \\
\text { progress. Access to products and participation in meetings is very important. This type of work } \\
\text { critical to achieving " } 20 \% \text { by } 2030 \text { " because we won't make progress if people don't buy into the } \\
\text { research and products. }\end{array}$ \\
\hline & $\begin{array}{l}\text { Good organization and should continue. Information sharing. Appropriate experts involved and } \\
\text { good credibility. NWCC needs stable funding. }\end{array}$ \\
\hline
\end{tabular}




\subsection{Discussion}

Interviews generally revealed broad support of NWCC's mission and work and belief that a collaborative forum focusing on technical aspects of environmental and siting issues is the right approach to addressing these issues. All but one respondent felt that environmental and siting issues are substantial barriers to wind energy development and several felt these issues are becoming more difficult. Respondents cited increasing numbers of wind facilities, increasingly long permitting timelines, and concerns over specific species (e.g., Indiana bat, sage grouse, golden and bald eagles) as reasons why environmental and siting issues continue to slow wind development. Some respondents also felt that issues perceived as wildlife issues may in fact be social issues presented as wildlife issues, such as noise and visual impacts. Other non-environmental issues that were mentioned as significant barriers are the ability to secure financing, connect to or establish transmission infrastructure, and create market demand for wind energy.

\subsection{NWCC Role and Purpose}

Over two-thirds of respondents felt that the NWCC/WW had made a difference in resolving environmental and siting issues. Some provided specific examples of products or events while others felt the contribution had been made in more general areas of collaboration, building understanding and relationships, and identification of issues. Respondents who did not believe that the NWCC had made a difference or who were undecided primarily came from natural resource agencies and industry. These respondents generally cited disappointment that NWCC had not been able to effectively resolve conflicts and big issues. "Big issues/conflicts" were never explicitly defined, but seemed to include, for example, no-development zones, establishing best practices, and policy issues. These respondents also cited the slowness of both the collaborative and scientific process and challenges inherent in developing regulations for a new industry as reasons why it was hard to determine whether the NWCC/WW had made a difference.

These results point to some disagreement about the NWCC/WW's purpose and whether it is the role of the NWCC/WW to raise and resolve big conflicts. An additional area of disagreement or confusion was around whether the NWCC's role is to promote responsible wind development or to serve as a neutral forum where support and opposition to wind industry are given equal weight. Some respondents felt that the forum was inappropriately biased towards wind energy development interests while others felt industry interests were underrepresented on the forum.

These disagreements or perceptions will be important for the NWCC to address and clarify because the way in which they are resolved will have broad implications on priority activities and member participation. Based on interview responses, securing industry buy-in and retaining industry participation seems to be most dependent on the NWCC's ability to resolve conflicts and big issues and to a lesser extent on appropriately robust industry representation.

\subsection{Overlapping Efforts}

The AWWI is a newly-formed, private non-profit governed by a board of directors and comprised of equal representation from wind energy developers and national environmental organizations. Agencies 
are represented by the Association of Fish and Wildlife Agencies only. Abby Arnold, the senior mediator for the NWCC, is the Executive Director of the AWWI. The AWWI is funded by membership dues, most of which come from industry, while NGOs tend to make in-kind contributions. The focus of the AWWI is research into wildlife issues affecting the wind industry, compilation of a research database, and development of mapping tools, mitigation strategies, and outreach and education materials. Recognizing similarities between the two organizations, staff of the NWCC and AWWI drafted a Memorandum of Understanding (MOU) to define how the two organizations would collaborate. While the MOU is not public, we understand that two ways the organizations intend to collaborate is that NWCC will advise the AWWI on research priorities and the NWCC will provide information synthesis and conduct outreach of AWWI research products (Arnold 2010).

While most respondents believe that the NWCC is unique in the services and products it offers, many respondents discussed some areas of overlap or perceived overlap with the AWWI. Areas of partial overlap cited by respondents include both organizations' focus on research into wildlife impacts and collaboration between some stakeholders (industry and NGOs primarily). However, respondents listed many more reasons why no redundancy exists between the two organizations. Reasons cited for distinction include some of the following:

Unlike the NWCC, the AWWI:

- is open to invited members only,

- is newly formed and therefore lacks a history of objective and credible research and products,

- does not represent all stakeholders, specifically natural resource agency participation is lacking, and

- is funded by membership fees derived primarily from industry and therefore may be perceived to have an industry bias.

Several respondents who mentioned one or more of the reasons above, did however, feel that the existence of the AWWI could diminish the importance of the NWCC in the long term. The two respondents who felt that the NWCC overlapped significantly with the AWWI both were from the industry sector and felt that the AWWI was a more productive forum for their needs. Additionally, two respondents cited a concern about perceived overlap or conflict of interest due to Abby Arnold's role in both organizations. Other organizations that were mentioned with respect to potential overlap were regional working groups formed around specific issues or projects, the Great Lakes Wind Collaborative, and the U.S. Offshore Wind Collaborative, although it was noted that none of these organizations have the breadth in scope of the NWCC and therefore were not considered to be redundant.

\subsection{Funding}

Most respondents (90\%) reported that federal or DOE funding is critical for providing products and services that are perceived as unbiased and independent and to ensure broad stakeholder participation in the NWCC. DOE participation specifically was considered helpful by many respondents because of the guidance and structure DOE's mission provided to the NWCC. Some respondents noted that DOE's involvement comes with a bias towards wind development, but that this bias could be effectively managed so as to not jeopardize the NWCC's objectivity and independence. 


\subsection{Value}

Many respondents reported that the NWCC is uniquely successful in its approach and highly respected for the quality of its research and technical products. Several respondents see the NWCC as an important mechanism to achieve DOE's stated goal of " $20 \%$ renewable energy by 2030 " because it promotes agreement on technical issues and critical buy-in on consensus-based solutions. The opportunity to collaborate with a variety of key stakeholders was the reason most cited by respondents for their involvement in the NWCC/WW. The services or products most cited as valuable were the semiannual research conference and research synthesis documents, such as the Methods and Metrics document, the Mitigation Toolbox, and Fact Sheets. These synthesis documents, however, also generated criticism from some respondents who were dissatisfied with their quality or utility (please see Appendix C). Although some respondents were disappointed with the NWCC's ability to address big issues (see 4.1) or feel that the NWCC overlaps with other organizations (see 4.2), most respondents reported negative consequences of discontinuation of the NWCC, including more polarization on environmental and siting issues, regression of issues previously seen as solvable to intractable, lost attention to wildlife issues, and less idea and information sharing. Many respondents expressed their high regard for the outside facilitation that supports the NWCC. The continuity of management of the NWCC also led some respondents to suggest that the involvement of new members and staff could reinvigorate the NWCC.

\subsection{Conclusions and Recommendations}

This study documents broad support of the function of the NWCC/WW and highlights some suggestions to improve the quality of the services and products provided by the NWCC/WW. Because this study presents an assessment of the NWCC derived primarily from its members or those with regular involvement, these results can be used to help understand the value and utility of the NWCC to a diverse range of stakeholders. Although addressed by some respondents, this work did not specifically evaluate contributions of the NWCC to the DOE's mission and strategic plan. Recommendations and points for further discussion among NWCC members and the DOE include:

- Distinctions in roles and points of collaboration between the AWWI and NWCC should be clarified. For example, the NWCC/WW should evaluate whether its role should be to conduct research, synthesize research, or both. Completion and release of the NWCC-AWWI MOU may help, but more details may be necessary.

- NWCC products could be made more useful to the target audience by improved outreach of products to state natural resource agencies, a higher level of detail and sophistication, and separation of scientific findings from a consensus-based editing process.

- NWCC's purpose and role should be clarified among its members and also with DOE. Specifically, NWCC should have a clear sense of whether the forum is expected to raise and solve big issues or areas of conflict relating to wind energy development and wildlife issues. This topic should be addressed considering the implications for participation on NWCC (i.e. who needs to be at the table). Tension about whether the NWCC serves as a neutral forum or promotes responsible wind development should also be discussed among NWCC members. 


\subsection{References}

Arnold, A. (2010). Personal communication at the Wildlife Working Group meeting, Lakewood, CO on October 22, 2010.

Kvale, S. (1996). InterViews: An Introduction to Qualitative Research Interviewing. Thousand Oaks, CA: Sage Publications.

NWCC (2010). National Wind Coordinating Collaborative website: http://www.nationalwind.org/. Accessed October 26, 2010. 


\section{Appendix A: Reasons for Involvement in the NWCC}

\begin{tabular}{|c|c|}
\hline \multirow[b]{3}{*}{ : } & aluable to be at the table with all the players who have vested interest. \\
\hline & $\begin{array}{l}\text { NWCC's function is forum for state and federal and local wildlife regulators and advocates } \\
\text { national and regional environmental groups and the wind industry can identify issues and get } \\
\text { issues addressed with technical, balanced, and credible info. Nothing like it in the world not to } \\
\text { mention the U.S. where this function exists. Going on for } 20 \text { years and it's been a model for } \\
\text { other collaborative }\end{array}$ \\
\hline & $\begin{array}{l}\text { The value of the NWCC is to meet and work through major challenges with siting with all major } \\
\text { stakeholders in a collaborative forum where you can proactively come up with solutions to these } \\
\text { challenges outside of the regulatory environment and outside of project specific controversy. It's } \\
\text { an opportunity to partner with other entities working to advance [wind energy] and NWCC } \\
\text { brokers good information exchange and tries to reach solutions. I think they got stuck on one or } \\
\text { two issues and haven't been as nimble moving on to challenges to address other barriers and } \\
\text { problems for renewable energy in general. NWCC is a good source of detailed information } \\
\text { around certain wind siting issues. }\end{array}$ \\
\hline \multirow{5}{*}{ 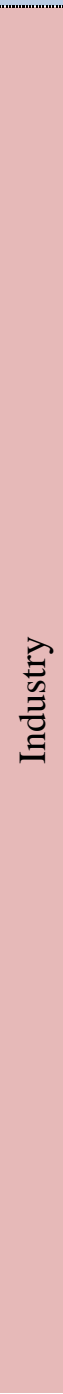 } & $\begin{array}{l}\text { To stay current on issues being brought up. Critical to have ongoing discussions on emerging } \\
\text { issues and identify solutions as they come up. General discussion has been most valuable from } \\
\text { my standpoint. }\end{array}$ \\
\hline & $\begin{array}{l}\text { Because there are few industry people represented and it's important to say involved. We need to } \\
\text { be there because this about us. And also about wildlife. }\end{array}$ \\
\hline & $\begin{array}{l}\text { Because NWCC has been for a long time one of the few arenas to get at wildlife impacts. So } \\
\text { from lack of any other avenue, we've wanted to support NWCC initiatives - Prairie chicken and } \\
\text { other grassland steppe species and sage grouse collaborative. NWCC was the only one } \\
\text { addressing this from technical perspective and not policy. Issues have been raised about } \\
\text { NWCC's effectiveness and those issues are unfair because stakeholders want answers before } \\
\text { science is ready. NWCC has been criticized as largely an academic exercise that doesn't illicit } \\
\text { actions that are useful in the policy world. Unfair. Personally, I'm not too engaged because there } \\
\text { are not a lot of industry people involved (largely contractors, NGOs, agencies, academics) so not } \\
\text { getting to answers that we needed from an industry standpoint. What was going on in } 2006 \text { is a } \\
\text { much different work environment than now. Now there are a variety of USFWS efforts, } \\
\text { (whooping crane effort, bald and golden eagle act programmatic permit...) that are also } \\
\text { addressing wildlife impacts from a technical and policy perspective. But NWCC is the only one } \\
\text { that's just focused on technical. The dynamic is such that industry wants to move at a place that } \\
\text { generally outpaces science/scientific understanding and public agencies try to bridge those two } \\
\text { temporal inconsistencies. Not necessarily a precautionary approach (i.e., "do nothing"), but not } \\
\text { "business as usual". And as science catches up, the policy/regulation adjusts accordingly. NWCC } \\
\text { informs the science but not so much the policy. }\end{array}$ \\
\hline & $\begin{array}{l}\text { AWEA was one of the main steering committee members so AWEA wanted to be involved in all } \\
\text { relevant aspects of NWCC. Found it a place where I could hear more about some of the concerns } \\
\text { and solutions and activities of academic community and regulatory folks working on policy and } \\
\text { try to understand where the solutions were. }\end{array}$ \\
\hline & $\begin{array}{l}\text { Consensus building policy dialogues have the ability to reach out into the future and bring people } \\
\text { together where things are not yet impacted in the partisan political process to build relationships } \\
\text { and develop ideas to later bring into the political process. If you do that then you can capture the } \\
\text { political process. That's how we set up the NWCC. Fundamentally it's between the suppliers } \\
\text { represented by AWEA and the buyers (utilities). Why involved? Thought it would be effective }\end{array}$ \\
\hline
\end{tabular}


and would help us to make change. NWCC helps me at all three levels at which I work (national, locally, regionally). I do all three and a lot of it is about relationships. So it's very important to have personal relationships with different people so you can adjust your own thinking and so that you can operate in the space that's between people's positions. Fundamentally NWCC helps to have relationships across different perspectives and that make progress possible. Can't get this from email and from the web.

We've always viewed NWCC as valuable because it's a neutral forum for stakeholders to engage and, whether the issue is transmission or wildlife. If AWEA put together an event, certain stakeholders may be uncomfortable participating and it's true that all the issues might not get aired. NWCC plays valuable role in providing that type of forum in which all stakeholders feel they can engage.

Assigned duty was to sit on what was called the avian subcommittee of the NWCC even before we addressed bat issues.

They [the NWCC] have a diverse group of stakeholders. I think it's heavily weighted towards

industry side. NWCC was good for me because I could keep abreast on the full spectrum of opinions, current thinking, agency actions, etc ....so just knowing what the other stakeholders thoughts were. We tried to identify things that would be useful and helpful to the entire stakeholder group.

Assigned duty. It's likely I'll stay involved

NWCC was the only opportunity at the time available to us to have a broad dialogue about these issues. To raise issues and concerns.

Because it's a group that focuses attention on issues that are important to my agency and that have relevance to the state (development of renewable and of minimizing effects on habitat and wildlife).

We've recently up'd our involvement in renewable energy. Have a renewable department now with a few people and that's all about furthering renewable energy use in the US and avoiding mistakes we made with hydropower in the ' $50 \mathrm{~s}$. We're involved in wind and bird strike issues and also solar siting. We promote renewable energy development, but in ways that don't cause wildlife issues.

Was asked and agreed to participate in conference prep. Agreed because conferences are

Z important because there are two levels of scientific exchange. $1-$ peer reviewed lit $=$ slow process and very one way exchange done in isolation. 2 - extremely valuable to participate in conferences especially if very focused.

There are other people from my organization also who are involved with NWCC. Our concern is the negative ecological impacts from wind development and we look at NWCC as a place we can go to exchange information and make contact with people.

Group meetings and workshops are good opportunity for people like us to understand where industry/agencies are going and what concerns are for agencies/permitting authorities. And an opportunity to learn what others are doing. It's also a good way for a consulting firm to stay connected.

I've been involved because they need my/my organization's expertise. Asked to help develop research priorities. I'd like to see that move to where my organization benefits more from the interaction, but at this point it's mostly because we have something they need. Consulting firms do most of the work for wind companies and my organization has been critical of their work and their depth and transparency and wanted to do more intensive work. Some companies ask for much more detailed work than most others. As long as my organization is engaged we need to be engaged in a format like the NWCC. NWCC doesn't do research and research shouldn't be the primary objective of the NWCC. Instead they should focus on presenting results and facilitating exchange. Scientific research shouldn't be consensus based. 
My organization was there from the beginning. Held the first research conference in 1994 because we were the ones trying to assess the issue so DOE could overcome barriers to

deployment.

From a national perspective, I participated at my organization because we were there from the beginning and wanted to keep it going. I moved employers, but wanted to stay involved because

very significant value to the nation. Critically important for expansion for wind in the US.

It's on the cutting edge [of science and wildlife issues]. All my competitors are there and clients are involved. It's a networking opportunity and a way to keep up with what's happening. 


\section{Appendix B: Activities, Services, Products of Most Value}

\begin{tabular}{|c|c|}
\hline \multirow{3}{*}{ 完 } & $\begin{array}{l}\text { Especially valuable are the documents around protocols or analyzing the impacts of wind power } \\
\text { on birds and bats. Lots of resource material and methodology and best practices that they've peer } \\
\text { reviewed and placed in public domain that have moved the conversation forward. Research } \\
\text { meetings are an opportunity for best minds on this issue to gather and trade info and solve } \\
\text { unknowns. NWCC has been a change agent in getting UWFWS to put together a much more } \\
\text { reasonable approach to dealing with wildlife. Also helped with creation of AWWI which is } \\
\text { putting more into research of unknowns. }\end{array}$ \\
\hline & $\begin{array}{l}\text { Proceedings of meetings and summaries of research agendas and priorities. Also having people } \\
\text { get together. }\end{array}$ \\
\hline & $\begin{array}{l}\text { NWCC provides studies and research meetings and methods and metric doc and a handbook on } \\
\text { use of those methods and metrics. We should be putting on workshops on how to use M\&M and } \\
\text { there are other new tools coming up. Need a continual peer review of materials coming out to } \\
\text { ensure they're well done and accurate. The function of expert review that NWCC has provided } \\
\text { informally needs to continue. NWCC has actually educated a group of experts about wind and } \\
\text { wildlife interactions. Like continuing education or like a virtual university. The expert workshop } \\
\text { is really amazing. We have 5-6 teams of experts reviewing abstracts. Two month effort and each } \\
\text { (36 people) put in } 20 \text { hours and no one paid for that. Huge benefit to DOE. }\end{array}$ \\
\hline \multirow{4}{*}{$\begin{array}{l}\vec{E} \\
\stackrel{\vec{E}}{\Xi} \\
\vec{\Xi}\end{array}$} & $\begin{array}{l}\text { I've not really relied on them [NWCC's products]. Did just complete an extensive review of the } \\
\text { M\&M document and took a lot of coordination. Not sure whether it was worth it for the } \\
\text { coordination. Can be painful to bring people to consensus in the industry and have a position that } \\
\text { all can agree on moving forward. }\end{array}$ \\
\hline & $\begin{array}{l}\text { Most valuable thing they do is research meeting in Oct. It should be annually. It took } 10 \text { years to } \\
\text { revisit methods and metrics doc and it has so many problems. Not valuable. Abby is working } \\
\text { with us, but it's just not working. Fact sheet was terrible. Maybe come up with an executive } \\
\text { summary for the M\&M that explains the purpose of the doc. It's not helpful when laundry lists of } \\
\text { unanswered questions are put together. It's always tempting to focus on what we don't know } \\
\text { rather than what we do. It's not fair to put that [resolving all those uncertainties] on the industry } \\
\text { and on the project. The research should be more focused. The Bat Wind Energy Cooperative is } \\
\text { very successful and Ed Arnett has done good job being successful. Very solution focused. } \\
\text { Founded by industry. Industry belongs to it through AWEA. Reasonable fees ( } \$ 25 \mathrm{~K} / \mathrm{yr} \text { ). They } \\
\text { listen to us and they are focused on solutions and started curtailment experiments. Successful } \\
\text { because solution oriented. }\end{array}$ \\
\hline & $\begin{array}{l}\text { Some good info came out of the grasslands steppe species studies out of Kansas State. Mitigation } \\
\text { tool box... I don't know how useful it is, but at the time it was a good collection of mitigation } \\
\text { techniques for the industry. Don't know if it has any legacy left to it. Sage grouse collaborative } \\
\text { is important because there are a variety of questions related to sage grouse in a variety of regions } \\
\text { and policies attempted around this question have been too precautionary so while we don't have } \\
\text { anything yet from NWCC it's a worthwhile investment. Important mechanism for stakeholders to } \\
\text { get together because not a lot out there that doesn't have a policy around it too. Like the golden } \\
\text { eagle program, it has a policy associated so it's always harder to have a technical conversation } \\
\text { around that. }\end{array}$ \\
\hline & $\begin{array}{l}\text { Birds and bats fact sheet did a fair job presenting information in a way AWEA couldn't do, for } \\
\text { example. Methods and metrics was also good. NWCC brings a lot of credibility. Also the } \\
\text { research meeting was the best place to find out what the latest was in a place not full of people } \\
\text { who didn't know anything about wildlife interactions where you make a list of research gaps and }\end{array}$ \\
\hline
\end{tabular}


have to otherwise start from the beginning every time. The research conferences are experts not starting from blank sheet of paper. I've suggested that they make the research meeting yearly.

The act of writing it down is most important because it becomes real then. Negotiate ok, but need to put it down on paper and so you can start to live with those words. That process of getting to compromise on documents is a valuable outcome.

I understand the most valuable service is the research meeting. Industry views that as an extremely valuable event to get at the latest scientific research that's out there. It's very detailed and in the weeds type event - not high level and that's very useful.

The NWCC forum provides an important avenue in my opinion to discuss issues and get issues on the table and move forward to next steps to address these issues and it provides a forum for my agency to explain to others where we're going [with regulations]. DOE should keep funding, because wind is a big issue.

Metrics and methods document was most important. It was a little bit vague, but it was the best thing going on at the time [in terms of guidance to industry]. Some other docs were developed afterwards that got watered down or were so basic that no one could get anything out of it. Those products were at an elementary level. Those products did get dialogue going and the potential for more was there. Not so sure that it [the methods and metric doc] is important now that we have federal guidelines?

Can't answer that yet.

I struggled with that a little bit because I'm looking at what state fish and wildlife agencies need and what they can get from NWCC. Bird and bat fact sheet and guidance docs are useful, but states haven't taken them up and used them as much as they could have. Maybe a capacity issue on the state's part. Also lots of overlap between NWCC issues (transmission, wildlife, siting) that it's hard to have them separate and producing products that are separate and useful. They all need to be working closer together and talking to each other. The solution could be as simple as how the NWCC is set up.

Research workshops and publications summarizing various presentations and discussions at the workshops because these provide a state of the art summary in terms of what's going on and the information that's been generated and can be used [to support decisions].

Both the forum and the products are very valuable. Research conferences are great. No particular products in mind, but peer reviewed research really important. Important to develop the science and disseminate it.

Research conference is important. Fact sheets are valuable too. They're updating the methods

O and metrics doc as well and that's extremely valuable. Strength of the NWCC is it's broadly Z representative.

Early on we hoped BMPs would emerge as valuable products and those have "sort of" panned out [but not entirely]. Why not entirely? Because it's a collaborative process and that means we come up with documents that aren't as stringent as we conservation interests want them to be sometimes. But some good standards do emerge.

\begin{tabular}{|c|c|}
\hline 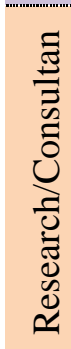 & $\begin{array}{l}\text { NWCC doesn't provide much outside of meeting minutes and proceedings and conferences. If } \\
\text { wasn't for NWCC workshops, lots of grey literature wouldn't have made it out or it wouldn't } \\
\text { have same impact. It [grey literature] gets more legitimacy than if it were just a report from a } \\
\text { company. Methods doc has been particularly beneficial. Cited lots and there is interest in its } \\
\text { update. Stuff they've produced has been quite influential. The service of providing a venue for } \\
\text { collaboration is really important too. Primary value is its collaborative nature and its somewhat } \\
\text { independence. If you had interest groups that try to drive process it wouldn't have been as } \\
\text { successful. }\end{array}$ \\
\hline
\end{tabular}


Coalescing information and providing tools is useful. The research meetings are extremely valuable for people to discuss industry science that may otherwise be suspect and get the chance to work out issues and learn about methods.

NWCC is an organization that has been responsive to the rest of its members. So products that have been produced over this period have been responsive to stakeholder input and for the most part they're consensus docs. Methods and metrics is especially valuable because helps assess impacts of birds from wind energy. That's a key one. Majority of docs were done by volunteers. Those docs provided or fit a need for what was needed at that time.

Primary contribution is the forum that the NWCC provides because no one else provides that with no agenda [no biases]. NWCC forum brings the regulators in (where they wouldn't likely come if the forum were sponsored by industry). Also very important in the transmission arena - we need to serve that function going forward and it's a related issue. NWCC provides a forum for people to really learn each other's positions and learn to appreciate and compromise. Over time we get people thinking seriously about how to deal with and use large amounts of wind power. This process [transforming and softening of positions] in transmission took place over 7-8 years and was catalyzed by the forum that NWCC provided. Similar in wildlife. And the annual conferences have become THE technical conference for people wanting to know the state of the art in environmental issues and science. Products of value from wildlife: metrics and measurements document is used and is one of the key resources for the wildlife and wind industry to guide actions. It was produced over years with expert involvement to be a credible and useful document. Fact sheets on what we know and what we don't know. There has also been specific projects that NWCC has catalyzed, cosponsored or been fund raisers to get the actual data to address emotional issues.

In general, NWCC is a great forum for the scientific community to keep up with each other and talk about new developments and I think it provides wonderful resource to the wind energy business /community for responding to the issues of the day and knuckling down and trying to find solutions to problems. 


\section{Appendix C: How to Improve the NWCC}

\begin{tabular}{|c|c|}
\hline \multirow[b]{3}{*}{ : } & $\begin{array}{l}\text { Carry out an outreach strategy associated with M\&M doc next year, more work on siting, more } \\
\text { partnering with NREL, fill outreach role for American Planning Association, providing consensus- } \\
\text { building training to other orgs, more work to serve as a clearing house of info, figure out how to } \\
\text { fund continual state involvement, collaboration with AWWI under new MOU (only barrier is DOE } \\
\text { uncertainty about recommitting the NWCC contract) }\end{array}$ \\
\hline & Could do more if were able to rely less on volunteer time \\
\hline & $\begin{array}{l}\text { Resolve, Inc should staff NWCC with more experienced staff (such as Abby) for better care and } \\
\text { feeding and to get the group to move forward. Now that a process exists to solve wildlife issues } \\
\text { (fed/state agency process), NWCC should go out and find the next dysfunctional issue to solve. } \\
\text { Consider gaps in coverage for offshore wind, such as ocean wildlife impacts. NWCC should be a } \\
\text { catalyst for focusing attention on new, emerging issues. NWCC could work to identify other major } \\
\text { challenges for wind, such as financing or sharing international information for mitigation uses, or } \\
\text { shift to MHK. The NWCC Steering Committee is too small and needs some fresh blood and new } \\
\text { thinking about governance structure to encourage more involvement from states and other feds. } \\
\text { Webinars and electronic interaction should be used to facilitate a broader discussion than just among } \\
\text { the Steering Committee. }\end{array}$ \\
\hline \multirow{6}{*}{$\stackrel{\overparen{E}}{\stackrel{\overparen{0}}{\Xi}}$} & $\begin{array}{l}\text { Membership is not balanced; it's skewed towards academics and scientists. Industry does not have } \\
\text { adequate representation. There are } 16 \text { non-industry seats, so there should be } 16 \text { industry seats. The } \\
\text { research meeting should be annually. More solution-focused research like out of Bat Wind Energy } \\
\text { Cooperative. Less research that lists all the unknowns because that's not helpful. Also there are } \\
\text { some personalities on the NWCC that are really not helpful or productive and therefore impeded } \\
\text { progress and broad participation. }\end{array}$ \\
\hline & $\begin{array}{l}\text { At times we would veer off into wildlife issues that were not the big questions. Fine line between a } \\
\text { place where everyone can bring up issues and keeping focus on the big issues. Concurrence on } \\
\text { documents should not be assumed if you're not heard from given the level of importance of these } \\
\text { issues. Not appropriate and causes problems later on. Solution is targeted outreach fro core group } \\
\text { to the members in the sector they represent. Some concerns from industry people that there's } \\
\text { insufficient industry representation, but I disagree. }\end{array}$ \\
\hline & Don't know \\
\hline & $\begin{array}{l}\text { NWCC should work harder to be clear on messaging on how it provides value to various } \\
\text { stakeholders and needs to do a better job to make sure that products do in fact provide the intended } \\
\text { value. }\end{array}$ \\
\hline & No ideas \\
\hline & $\begin{array}{l}\text { NWCC could improve its work if it had DOE support. Previous support has eroded and now we're } \\
\text { playing a game of "bring me a colored rock". This lack of support makes it difficult to get anything } \\
\text { done. Mobilizing an industry will require support and getting information and sectors together in a } \\
\text { way that's backed up with serious work. NWCC focusing across all renewables where there are } \\
\text { common issues could be a way to get broader buy in and provide more service. }\end{array}$ \\
\hline \multirow[t]{2}{*}{ 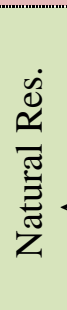 } & $\begin{array}{l}\text { NWCC products could be made more useful/accessible to states. NWCC produces great, neutral } \\
\text { science, but states don't have the capacity to use it. NWCC could do a better job translating or } \\
\text { messaging to a certain group of people who might use the material. State participation used to be } \\
\text { funded, but now it's not. State participation has suffered as a result. Coordination within NWCC } \\
\text { (between transmission, siting, wildlife) could be improved. }\end{array}$ \\
\hline & $\begin{array}{l}\text { Better coverage of fast breaking issues to educate members about things that happen in between } \\
\text { research meetings. Perhaps a web-based database could contain findings and new research with }\end{array}$ \\
\hline
\end{tabular}


application to siting decisions.

Some documents were so watered down by the consensus process that they were not useful and were at too much of an elementary level. The potential for more in-depth, sophisticated products is there, so NWCC could work harder to make useful products. They should also broaden the base of who writes the documents. The facilitator was very good in many respects, but often they were more interested in getting a product out rather that doing it the right way or getting the right product out. They should push to get more involvement rather than taking the easy way out and trying to please everybody.

Don't know yet

NWCC should push for more peer review and publication on findings developed in the referenced scientific literature.

NWCC publications bring together current state of knowledge, but NWCC should work to provide more frequent updates of products to remain current. Specific for each product, should develop an update timeline. NWCC should carefully consider their role with respect to offshore wind.

NWCC should consider providing leadership to federal effort to categorize good sites for offshore development. DOE should focus on offshore wind wildlife issues. NWCC should continue work on bat deterrents and prairie grouse. Structure is good and so is the mix of members. Parts of NWCC (transmission, siting, wildlife) could communicate/coordinate better.

Ideally NWCC would establish best practices for the industry, but not sure if that's realistic. NWCC could be retooled to be more effective.

Research shouldn't be the primary objective of the NWCC because scientific research shouldn't be consensus based. Instead it should be presenting research results and facilitating exchange. There is a sense that NWCC is extremely biased towards industry and DOE interests. It's balanced in terms of players, but not outcomes. It's not a neutral forum. To make it neutral, divergent opinions need to be present and also to be listened to. Changing where funding comes from could address this issue. The M\&M doc and fact sheets were useful, but science needs to be separated from consensus because the science got watered down. For that same reason, the current M\&M doc can't be considered a science document. I don't think opposition to wind has been taken seriously as it should be. Meeting opposition head on is important and NWCC could do a better job at this.

The function of NWCC should continue, but DOE should put the task of running the NWCC out for competitive bid. DOE would need to think hard about the purpose and what functions are most important and should be maintained, but should be careful not to over constrain. Not intended to reflect dissatisfaction with Resolve, Inc - it's been well run - but things have changed and staff are involved in lots of other activities and it makes it hard for them to give adequate focus to NWCC. Also uncertainty over NWCC funding for last few years makes it hard to focus and get NWCC work done. That insecurity could be soothed if DOE committed to funding NWCC in a competitive bid. I think it would rejuvenate interest in NWCC work. I wonder if NWCC could be expanded to cover similar environmental and siting issues for other renewable sources. The function of NWCC (a forum and developing data) is needed among other renewables.

Good job running research meetings like science conferences and using the NWCC collaborative process to refine products. However, NWCC has never been able to bring about real change and only occasionally brokered projects to address these risks/issues. This is where NWCC is weakest and they could do more here. They don't lack interest, but are trying to follow a mandate. NWCC has not yet moved to focus offshore, but they may have to as there will be even more focus in the future.

The collaborative process means that timeline for completing products is worse than a snails pace. Funding could help here. Need a way to move products quicker.

Better funding would allow NWCC to improve its work so they don't have to beg industry to fund important studies. It took a year to get prairie chicken funding and Abby's beating the bushes for sage grouse [funding]. 


\section{Appendix D: Similar Services or Products}

\begin{tabular}{|c|c|}
\hline \multirow{3}{*}{ 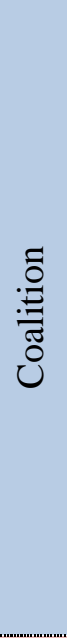 } & $\begin{array}{l}\text { NWCC is absolutely unique in what it does. NWCC and AWWI have different functions. } \\
\text { AWWI will hopefully support and encourage more research. NWCC is home of two research } \\
\text { collaborative (prairie chicken and sage grouse) and it's not appropriate for NWCC to raise } \\
\text { millions of \$ for grouse research. AWWI should sponsor this research and do studies. NWCC } \\
\text { should do outreach for all that good work. NWCC is open to anyone. It's the perfect role for } \\
\text { government. }\end{array}$ \\
\hline & $\begin{array}{l}\text { AWWI is a partnership or membership organization. Industry pays membership dues. NGOs } \\
\text { make in-kind contribution. Some activities revolve around what members have voted on and } \\
\text { what they interested in. So less free flowing than NWCC. NWCC Wildlife is highly focused on } \\
\text { research agenda. In AWWI siting is the issue. Wildlife is part of siting but AWWI is looking for } \\
\text { tools and ways to inform the public and also AWWI is fairly new. NWCC is open and anyone is } \\
\text { invited. }\end{array}$ \\
\hline & Not really \\
\hline \multirow{6}{*}{ 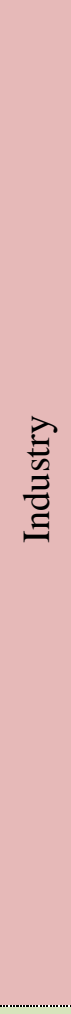 } & AWWI is similar. \\
\hline & AWWI. Same thing as NWCC. A higher level of people at the table. \\
\hline & $\begin{array}{l}\text { NWCC is lacking what other efforts have. For example, AWWI has stepped in to fill a void } \\
\text { that's been missing - an equal partnership between AFWA, NGOs, and industry. Governed by } \\
\text { all these. They enable research specific to wind and wildlife impacts. Has the same mission, but } \\
\text { they don't occupy the same space, but same proximity. }\end{array}$ \\
\hline & $\begin{array}{l}\text { Don't know of another place where you get this. There are spin-offs, like Great Lakes Wind } \\
\text { Collaborative, and the Atlantic Governors have an agreement for the offshore.....and we're using } \\
\text { the tools of collaboration here in the west. To hear Obama talking the right now [you think } \\
\text { there's really support for wind] talk and then these DOE guys saying "bring me a different } \\
\text { colored rock". It's frustrating. The Commander in Chief wants to double renewable energy in } \\
\text { three years and to solve this transmission issue so DOE bureaucrats need to get out of the way. }\end{array}$ \\
\hline & $\begin{array}{l}\text { Don't really think there is anyone else who does the same work. Closest with AWWI and I don't } \\
\text { believe it overlaps. AWWI is not open to just anyone and I think it's focused on supporting } \\
\text { specific kind of research and some big dollar research projects where industry wouldn't have put } \\
\text { up \$ unless they had a bit more say. No agencies there. They have no formal roll. NWCC is the } \\
\text { place where ideas are hatched and brought up and discussed and AWWI is where implemented. }\end{array}$ \\
\hline & $\begin{array}{l}\text { AWWI comes to mind, which was launched a couple years ago. The board is split between } \\
\text { industry and NGOs, but they have a very targeted mission and they don't actually have any } \\
\text { output or products at the moment. So I don't think they're mutually exclusive efforts. A } \\
\text { difference is that AWWI has no government role. }\end{array}$ \\
\hline \multirow{2}{*}{$\stackrel{\widetilde{T}}{\stackrel{\overparen{E}}{E}}$} & $\begin{array}{l}\text { NWCC has been an important forum, we don't have anything like the NWCC elsewhere for } \\
\text { wind. Heavily represented by industry, but that's good. }\end{array}$ \\
\hline & $\begin{array}{l}\text { Not, but AWWI might be similar. People were upset when AWWI formed because industry } \\
\text { picked and chose people to be on that. Don't believe there is anyone else out there [any other } \\
\text { organization] who gets the diversity piece in so well as NWCC. }\end{array}$ \\
\hline
\end{tabular}


It's gotten more complicated now so there are other places to talk to other groups. AWWI also. ...so community has gotten more complex which means NWCC is needed even more and it takes effort away from NWCC because we're spread thinner. Other places/entities don't play the same role, but there are a lot of other obligations of time out there. Lot of other groups, but we all have a different niche. AWWI has another focus.

Things [other groups] have grown up since then [when NWCC started]. There are regional working groups that are working on state or regional basis. E.g. Great Lakes Wind Collaborative, Western Governors, etc. And AWWI which is looking more on a national basis... but the main concern is that they may not have the standing in the field that NWCC does. They're [AWWI] not yet established in terms of their credentials. NWCC objectivity and scientific accuracy is respected. If other groups like AWWI manage to establish with as good of reputation nationally speaking, they could probably step into part of NWCC's role from a scientific standpoint.

No redundancy. This is a unique opportunity to get people working together. There has been some local collaboration, but nothing at this scale.

AWWI will eventually fill some of the role that NWCC is filling, but it doesn't yet. It's going to need substantial growing phase (i.e. years).

I've been wondering how the offshore wind collaborative will relate to the NWCC. OWC has non profit and agency reps, but maybe it's similar to trade organization. I don't think it's focusing as much on environmental issues. NWCC focused more on land based wind and

NWCC should look carefully about what their role is with respect to offshore wind energy

$\mathrm{Z}$ development. I supported including offshore wind development in the semi-annual research conference. The papers submitted were pretty thin. Also the AWWI [is similar to the NWCC]. No federal agency involved in paying for that.

There is a lot more investigation [into wildlife impacts] and development of standards in the renewable industry in general today than there was even five years ago. There is still a role for NWCC to play in bringing people together in a consistent manner.

Not really

N No, lots of activities going on with wind and wildlife, and lots of overlap, but no one is doing it like this (big round table of stakeholders). So yes, unique.

के No, with respect to the wildlife workgroup. Because wildlife meetings may be 30-40 people

¿ sitting there and why would they waste time sitting there on a monthly basis if there was another mechanism to get that info. Another reason is that the sage grouse collaborative that was in development for over a year, they got together and then asked to be part of the NWCC to take advantage of the experiences on the prairie chicken.

No one else provides a forum without a vested interest from someone.

AWWI does some similar things although there are some huge efforts to make sure they're not overlapping. AWWI has seed money to support research in wind industry. One of AWWI's goals is education. But they're not overlapping or redundant. 


\section{Appendix E: Consequences of Discontinuation of the NWCC}

\begin{tabular}{|c|c|}
\hline \multirow{3}{*}{ : } & $\begin{array}{l}\text { Attention would be lost to these issues and people wouldn't be able to reasonably keep up. Support } \\
\text { in achieving the " } 20 \% \text { by } 2030 \text { " goals. Long record of success, unique and collaborative approach, } \\
\text { model for other collaboratives }\end{array}$ \\
\hline & $\begin{array}{l}\text { It would be unfortunate. If NWCC were discontinued, AWWI could take on some functions (esp } \\
\text { the wildlife workgroup), but not yet able to at this time. }\end{array}$ \\
\hline & $\begin{array}{l}\text { There would be less of a conduit to DOE and NREL from major stakeholders so DOE wouldn't get } \\
\text { the pulse of what's happening in land based wind. We'd go back to silos with poor info exchange. } \\
\text { We'd lack an ability to dig deeply into significant challenges facing wind power. }\end{array}$ \\
\hline \multirow{6}{*}{ 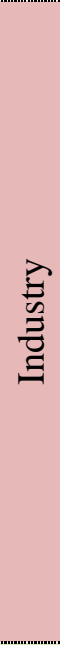 } & $\begin{array}{l}\text { I don't think industry would miss it. Some stakeholders who otherwise don't have a voice would } \\
\text { miss it. Someone else would pick up the research meeting. It might be good to clean house (not } \\
\text { intended to reflect badly on Resolve, Inc) and reinvigorate and re-excite members. DOE could put } \\
\text { money into AWWI research initiatives. }\end{array}$ \\
\hline & $\begin{array}{l}\text { We'd lose a helpful place to vet issues and no one else is providing this. Other groups can help fill } \\
\text { this need, but NWCC has the longest track record. }\end{array}$ \\
\hline & $\begin{array}{l}\text { It would force organizations like AWWI to try to fill some of that role. It would set back the level } \\
\text { of information available to stakeholders about wildlife impacts. It'd be a bad thing. }\end{array}$ \\
\hline & $\begin{array}{l}\text { Not much impact from industry perspective, but it would be a loss in terms of ability to have an } \\
\text { open dialogue and dissemination of information. }\end{array}$ \\
\hline & $\begin{array}{l}\text { Some issues could become thornier. Someone would need to hold the research conference, but hard } \\
\text { to find a neutral party to do that. }\end{array}$ \\
\hline & $\begin{array}{l}\text { We've built a terrific network thru NWCC to get to } 20 \% \text { by } 2030 \text { and if you tear that apart, to some } \\
\text { extent it'll still work but at a lower level. }\end{array}$ \\
\hline \multirow{5}{*}{ 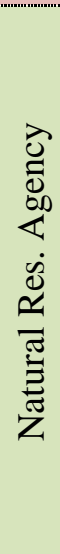 } & $\begin{array}{l}\text { The "big, round table" function would be lost and I don't think anyone else would pick it up. The } \\
\text { research conversation could move forward with AWWI, but they're not focused on identifying } \\
\text { priorities like NWCC is. }\end{array}$ \\
\hline & $\begin{array}{l}\text { The main thing lost would be a communications channel that would be very difficult to reestablish. } \\
\text { And access to the expertise on NWCC in one place. It's not always easy to reestablish that kind of } \\
\text { truly collaborative, broad based approach in a field that can be complicated and controversial. }\end{array}$ \\
\hline & $\begin{array}{l}\text { Not sure NWCC helped with siting issues, but what would be lost if it were discontinued is the } \\
\text { education to members about best available science and what siting decisions need to be considering }\end{array}$ \\
\hline & $\begin{array}{l}\text { It's worth continuing because these issues have bounced around for a long time without making } \\
\text { progress and some large solutions are required. }\end{array}$ \\
\hline & $\begin{array}{l}\text { We'd lose this opportunity to discuss issues and get issues on the table and explain to others our } \\
\text { direction/thoughts. Any what else would take its place? }\end{array}$ \\
\hline \multirow{3}{*}{ ○ } & $\begin{array}{l}\text { We'd lose a very useful forum with very broad membership. I'm not sure industry would suffer } \\
\text { from the loss of NWCC, but other members would. }\end{array}$ \\
\hline & $\begin{array}{l}\text { There would be less hard data and less information sharing between industry and conservation } \\
\text { groups and others and the problems that are turning out to be solvable would regress into being } \\
\text { intractable. }\end{array}$ \\
\hline & $\begin{array}{l}\text { NWCC still has value and if discontinued there would be some loss, but not as much as if NWCC } \\
\text { were to retool and become more comprehensively connected to wildlife and industry and pull } \\
\text { players under one tent to exchange information and develop compromises. It would be a bad thing } \\
\text { if NWCC went away. }\end{array}$ \\
\hline
\end{tabular}


There would be no table to gather around.

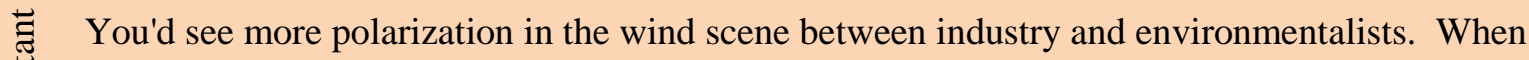
people don't talk they tend to think the worse of each other and over time the relationships

deteriorate. NWCC has headed that off and no one else is out there to do that.

Wildlife issues would get bigger and nastier before they get addressed, but not sure if it would slow

down development progress. Permitting would be more difficult, take longer, and therefore be more

ฮँ expensive because NWCC wouldn't be identifying high priority problems.

$\widetilde{a}$ Things would become very disjointed and that would be a very inefficient use of limited resources. We'd have no mechanism to hear about complementary research in the country.

It would be horrible. No one else gets into the nitty gritty and pushes the wildlife workgroup to answer some of the tough questions. 


\section{Appendix F: Comments on Value of the NWCC}

\begin{tabular}{|c|c|}
\hline \multirow{3}{*}{ ن̃. } & $\begin{array}{l}\text { Model for other collaboratives for going on } 20 \text { years. Nothing like it in the world. Forum to get } \\
\text { issues addressed with technical, balanced, credible info. }\end{array}$ \\
\hline & $\begin{array}{l}\text { Wind and wildlife issues are important and not being resolved. Wind will need to be part of the } \\
\text { equation for a renewable energy future in the US. Expertise at NWCC is extraordinarily valuable. }\end{array}$ \\
\hline & $\begin{array}{l}\text { NWCC has been a change agent in getting UWFWs to put together a much more reasonable } \\
\text { approach to dealing with wildlife. Also helped with creation of AWWI which is putting more into } \\
\text { research of unknowns. My sense is that current DOE leadership doesn't value this kind of outreach, } \\
\text { but they're wrong; technology is important, but dealing with lack of information and policy } \\
\text { challenges is also really important. }\end{array}$ \\
\hline \multirow{6}{*}{ 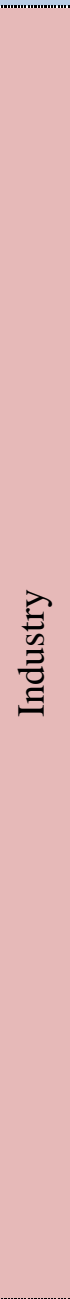 } & $\begin{array}{l}\text { The NWCC is like rolling a strong uphill; it's hard to get stuff done because there are so many } \\
\text { varying perspectives. The good news is that everybody has a voice. That's also the bad news. } \\
\text { Abby is the best facilitator ever. No comparison to her. NWCC products were not of value and } \\
\text { took forever to develop (fact sheet and methods and metrics). Before we didn't have the AWWI and } \\
\text { now we do so the need for NWCC is diminished and plus representation is much better (50:50 } \\
\text { industry to NGO). }\end{array}$ \\
\hline & $\begin{array}{l}\text { NWCC brings a lot of credibility to their products. The research meetings were the place to have in } \\
\text { depth dialogue with the experts in this field. Very valuable. There may be a role for NWCC's } \\
\text { coordination role for offshore wind in bringing information out. But not helpful at this point to } \\
\text { make a long list of unknowns. }\end{array}$ \\
\hline & $\begin{array}{l}\text { Criticisms about NWCC being largely an academic exercise and not very effective are unfair } \\
\text { because the science is not ready yet and stakeholders always want answers before the science has } \\
\text { caught up. NWCC is the only venue where issues are just addressed technically and not policy- } \\
\text { wise. Hard to say if there has been practical use from the NWCC, but we'd be much further behind } \\
\text { the overall conversation if it weren't for the NWCC. }\end{array}$ \\
\hline & $\begin{array}{l}\text { Not sure how valuable the products have been. Very hard to get review on them from industry and } \\
\text { not sure its worth the effort. Value of NWCC is research and advancing knowledge of the science, } \\
\text { but it's not been particularly effective at resolving conflicts. Industry most fears "no development } \\
\text { zones" and the drive for no-go zones has set up battle lines. Since NWCC is not effective at } \\
\text { resolving those divides, maybe better to focus on the latest data and disseminating it. If NWCC lost } \\
\text { federal funding, losing that grounding would make it even less effective than how its currently } \\
\text { structured. I'm not sure that anyone in industry knows what the purpose of NWCC is at this point. }\end{array}$ \\
\hline & --- \\
\hline & $\begin{array}{l}\text { NCWW has convened dialogues on many important topics and then spun them off for someone else } \\
\text { to pick up. Most valuable is the act of writing down what we've agreed on because then it becomes } \\
\text { real and not just negotiations. It's the process of getting to compromise that is a valuable outcome. } \\
\text { I'd like to know DOE's alternative to getting this work done if they don't like the NWCC approach. } \\
\text { What's their alternative? Competitive solicitations don't gain you the trusted communication in the } \\
\text { association world where change happens. }\end{array}$ \\
\hline \multirow{2}{*}{ 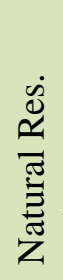 } & $\begin{array}{l}\text { We've developed some great relationships with folks that never would have happened had there not } \\
\text { been a NWCC }\end{array}$ \\
\hline & $\begin{array}{l}\text { Look to other literature on wildlife topics and you'll see how widely cited NWCC work is. Other } \\
\text { organizations wouldn't be where they are if it wasn't for NWCC. In person participation by states is } \\
\text { really critical and we need to find a way to fund this in the future. }\end{array}$ \\
\hline
\end{tabular}


It was valuable to use the NWCC for public briefings on FWS siting guidelines. Abby is a good, strong facilitator. DOE should continue to try to fund NWCC into the future and continue to move the dialogue forward and we really need a tool chest of best practices and funding is critical. Representation is industry heavy.

The strength of the NWCC is it's broad representation. If NWCC went to membership fee funding, they'd have to ask what would then be the difference between AWWI and NWCC. NWCC should consider its role with respect to offshore wind.

---
NWCC is valuable in creating a forum for dialogue between conservation and industry folks.
(mapping, research) so the existence of AWWI may diminish the importance of NWCC. I'm not
sure DOE is unbiased in terms of how the wind industry should be developed with respect to
wildlife impacts so there is a risk that this funding drives NWCC to a less broad perspective than if
it came from an entity not perceived to be affiliated with industry.
NWCC has not yet solved complex problems partly for political reasons because science almost
always trails behind politics and decision making. The public doesn't distinguish a difference
between industry and DOE funding. DOE or industry funding doesn't have to be toxic, but the
perception needs to be managed. It's noted that Abby is involved with a lot of other things. She
does a good job, but perceptions matter.

No one else provides this type of forum with out an agenda. NWCC provides a forum for people to really learn about each other's positions, to appreciate those, and to compromise. NWCC is a catalyst for making progress on issues. Research conferences are THE technical conference for state of the art in wildlife issues and science. NWCC products are produced over years with expert input so they're credible and useful documents. Other funding sources are possible but problematic (foundations want to fund policy and industry funding threatens credibility).

NWCC research meetings and proceedings air grey literature and give it legitimacy. NWCC products have been quite influential. The primary value of the NWCC is the collaboration function. NWCC's impact is that people can sit around a table with each other and talk with each other with respect (contrasted to 1994 meeting). The ability of the facilitator to listen and translate is extremely valuable. Facilitation has been very valuable to moving the conversation forward. Charging fees to participate or buy use of products, would decrease participation/use. It would be a shame to see someone left out because they couldn't afford to participate. Environmental and siting barriers need to be overcome in order to move forward and these concerns are a key barrier to deployment. If DOE wants to get to $20 \%$ by 2030 , we need to get people to work together because this is one of the strongest mechanisms to overcome these issues. The research is critical, but if people don't agree to it it's not good. There is significant value in the concept of NWCC. In an industry as competitive as wind, it's miraculous how well they get together and share info. NWCC has doen a good job getting the right people to do research and manage a review process with good credibility. NWCC is a great organization and it really needs to keep going. It'd be nice if it could be supported by stable funding because it takes so much energy to fund raise. 




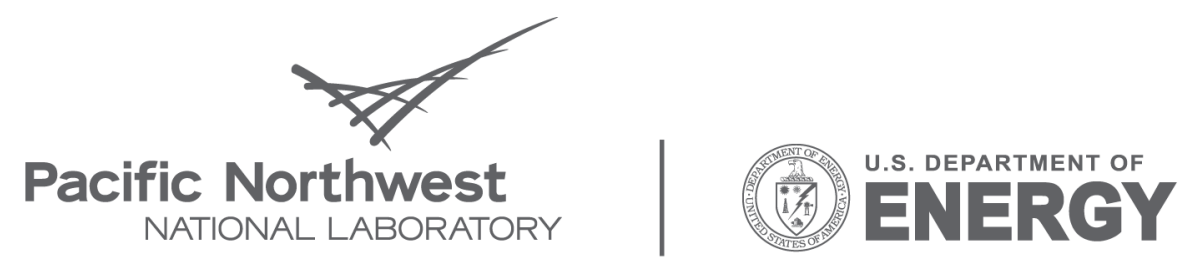

Proudly Operated by Battelle Since 1965

902 Battelle Boulevard

P.O. Box 999

Richland, WA 99352

1-888-375-PNNL (7665)

www.pnl.gov 